\title{
LÄÄKÄRIN TYÖTILANTEIDEN KIELELLISEN VAATIVUUDEN MÄÄRITTÄMINEN
}

\author{
Maija Tervola, Tampereen yliopisto
}

\begin{abstract}
Työelämän kielitaidon koulutuksen ja testauksen tueksi tarvitaan tarkempaa tietoa siitä, millaista kielitaitoa eri aloilla ja ammateissa vaaditaan. Nykyään vallalla on näkemys, jossa kielitaitoa pidetään tilanteisena taitona, mutta tilanteen käsitettä ei ole juurikaan määritelty eikä tilanteiden ominaisuuksia eritelty. Tässä artikkelissa tarkastellaan lääkärin työtehtävien kielellistä vaativuutta työyhteisön jäsenten haastatteluiden avulla. Terveydenhuollon ammattilaisten ryhmähaastatteluista $(n=32)$ etsittiin temaattisen sisällönanalyysin avulla sellaisia työtilanteiden ominaisuuksia, jotka ovat yhteydessä maahanmuuttajataustaisten lääkärien kielelliseen suoriutumiseen. Löydetyt ominaisuudet liittyvät muun muassa tilanteen seurausten vakavuuteen sekä tilanteen osallistujiin. Analyysin tulosten perusteella muotoiltiin kymmenen kriteeriä lääkärin työtilanteiden kielellisen vaativuuden määrittämiseksi: kriittisyys, sosiaalinen vastuu, yhteinen taustatieto, sosiaalinen variaatio, sosiaalinen tuttuus, kommunikoinnin monisuuntaisuus, tilanteen harvinaisuus, kiireellisyys, kieliriippuvuus ja häiriötekijät. Kriteerien tarkoituksena on parantaa erityisalojen kielikoulutuksen ja -testauksen validiutta suhteessa työssä vaadittavaan kielitaitoon. Kriteerit on abstrahoitu aineistosta siten, että niitä voi soveltaa muihinkin ammatteihin, mutta toisaalta muiden ammattien konteksteista saattaa nousta esiin myös uudenlaisia kriteereitä.
\end{abstract}

Avainsanat: ammatillinen kielitaito, kielitaitovaatimukset, kriteerit, lääkärit, suomi toisena kielenä, työtilanteet

\section{JOHDANTO}

Importantly, if we do not understand situations, we will not understand person-situation interactions.

(Johns, 2006, s. 388.)

Nykyinen suuntaus kielenopetuksessa painottaa työelämään ja ammattialoille kohdistettua kielitaitoa (Huhta, Johnson, Lax

Kirjoittajan yhteystiedot:

Maija Tervola

COMS, 33014 Tampereen yliopisto

maija.tervola@staff.uta.fi
\& Hantula, 2006; Sajavaara \& Salo, 2007; Härmälä, 2013). Tämä näkyy erityisesti S2alalla, jossa työelämän kielitaito on noussut huomion kohteeksi laajalti (ks. esim. Kela \& Komppa, 2011; Kokkonen, 2007; Strömmer, 2016; Virtanen, 2017). Maahanmuuttajien kotouttamispolitiikassa kannetaan erityistä huolta kotoutettavien työllistymisestä ja työelämävalmiuksien hankkimisesta; jo kotoutumiskoulutuksen aikana pyritään tarjoamaan ammattialapainotteisesti suuntautunutta kielenopetusta (OKM, 2016, s. 25). Ammatilliseen koulutukseen kohdistuvien uudistusten tavoitteena on yhä enemmän integroida kielenopetusta ammatilliseen opetukseen (OKM, 2017, s. 13). Suomessa on käynnissä 
useita hankkeita, joissa pyritään yhdistämään ammatillisen osaamisen ja siihen liittyvän kielitaidon hankkiminen (ks. esim. Kielimuurin yli, 2013; Eskola-Kronqvist \& Hirard, 2016; Maahanmuuttajalääkärin koulutuspolku, 2017).

On kuitenkin suurelta osin vielä epäselvää, millaista kielitaitoa milläkin ammattialalla tarvitaan (ks. esim. Huhta, Jaatinen \& Johnson, 2006; Jäppinen, 2010; Tarnanen \& Pöyhönen, 2011). Eri ammateille asetetut kielitaitovaatimukset voivat poiketa toisistaan paljonkin, eivätkä ne useinkaan perustu ammatin käytännön tarpeiden analyysiin. Esimerkiksi luokanopettajilta vaaditaan erinomaista taitotasoa mutta lääkäriltä vaaditaan vain tyydyttävää taitotasoa (Asetus 1998; Asetus 2003; Valvira, 2016). Ammatillisten tutkintojen opetussuunnitelmissa kielitaitotavoitteet ja -vaatimukset on määritelty väljästi (OPH, 2015). Tarkempi perehtyminen kunkin ammattialan kielellisiin vaatimuksiin ja käytänteisiin on yksittäisten kielenopettajien omalla vastuulla (Huhta, Jaatinen ym., 2006; Juurakko-Paavola \& Mård-Miettinen, 2012). Joillekin aloille on luotu myös tarkempia ammattialakohtaisia kielitaidon viitekehyksiä (Huhta, Johnson ym., 2006; Komppa, Jäppinen, Herva \& Hämäläinen, 2014), jotka pohjautuvat ammattiopettajien kanssa tehtyyn yhteistyöhön ja ammattilaisten haastatteluihin tai alan opiskelijoiden ja työnantajien haastatteluihin (Kela \& Komppa, 2011; Jäppinen, 2010). Viitekehysten tekijät toteavat, että työtehtävien kielellinen vaativuus vaihtelee (Komppa ym., 2014, s. 12), mutta toistaiseksi käytössä ei ole välineitä niiden kielellisen vaativuuden arvioimiseksi.

Varsinkin terveydenhuoltoalalla on havaittu, että kielitaitoon liittyviä ongelmia kohtaavat työssään nekin työntekijät, jotka ovat saaneet yleisissä kielitesteissä hyvät arviot (Mahajan \& Stark, 2007). Lukuisissa tutkimuksissa ammatti- tai alaspesifit kieli- testit ovat osoittautuneet herkemmiksi työssä tarvittavan kielitaidon indikaattoreiksi kuin yleistä kielitaitoa mittaavat testit (Chur-Hansen, Vernon-Roberts \& Clark, 1997; Eggly, Musial \& Smulowitz, 1999; Boulet, van Zanten, McKinley \& Gary, 2001; Baig, Violato \& Crutcher, 2009). Yleistä kielitaitoa mittaavien testien käyttö ammatillisen kielitaidon arvioinnissa näyttää siis olevan ongelmallista validiuden kannalta. Eräs mahdollinen selitys tälle on, että yleiskielitaitoa mittaavien testien tehtävistä puuttuu sellaisia ominaisuuksia, jotka tekevät autenttisista työtehtävistä kielellisesti vaativia. Tällaisten testien tarkoituskaan ei tosin ole mitata spesifeissä työtehtävissä vaadittavia kielellisiä taitoja, mutta monien autenttisessa elämässä esiintyvien haasteiden puute voi tehdä kielitesteistä liian helppoja ja heikentää siten niiden perusteella tehtävien johtopäätösten luotettavuutta. Myös taloudelliselta kannalta on ongelmallista, jos kielikoulutuksen tai testin arvioon ei voida käytännössä luottaa (Tarnanen, Huhta, Pohjala, 2007, s. 386).

Monet tutkijat ovat lisäksi huomauttaneet, että yleiset käsitykset ammatillisesta kielitaidosta ja sen riittävyydestä saattavat olla jyrkkiä ja joustamattomia (Virtanen, 2011; Tarnanen \& Pöyhönen, 2011). Kun alojen ja ammattien todellisista kielitaitovaatimuksista ei ole pitävää tietoa, ovat työnantajat ja muut asianosaiset usein tyhjän päällä arvioidessaan kielitaidon riittävyyttä työtehtävässä (Komppa, 2015). Tällöin helposti ennakkoasenteet pääsevät vaikuttamaan liikaa, ja kielitaitovaatimukset voidaan asettaa liian tiukoiksi tai liian löyhiksi, mikä voi johtaa eettisiin ongelmiin ja vaarantaa yhdenvertaisuutta (Tarnanen \& Pöyhönen, 2011, s. 150; Lilja, Luukka \& Latomaa, 2017, s. 21). Kielenopettajien ja kielitaidon testaajien tulee pystyä perustelemaan, mihin asetetut tavoitteet ja vaatimukset perustuvat (Huhta, Johnson ym., 2006, s. 38). Ammattien todellisia kielitaitotarpeita 
kartoittaville tutkimuksille on siis suuri tarve, jotta kielitaitovaatimukset voitaisiin perustaa epätäsmällisten käsitysten sijaan tietoon.

Kun tavoitteena on tutkia ammatin tai alan todellisia kielitaitotarpeita, luonteva lähtökohta on tutkia ammattiin tai alalle kuuluvia työtilanteita ja kielellistä suoriutumista niissä. Tämä tutkimus esittelee yhden tavan tarkastella ammattiin kuuluvia työtilanteita ja analysoida niitä suhteessa ammattilaisten kielelliseen suoriutumiseen. Pohjana käytetään lääkärin työstä saatua tietoa, kuinka erilaisissa työtilanteissa suoriudutaan kielellisesti. Kielellisen suoriutumisen mittapuuna käytetään työtilanteen onnistumista, jota arvioivat erityisalan asiantuntijat (ks. esim. Pill \& McNamara, 2016). Työtilanteiden ominaisuuksien tarkastelu pohjautuu terveydenhuollon ammattilaisten haastatteluihin, mutta tutkimuksen kohteena eivät kuitenkaan ole ammattilaisten kokemukset ja käsitykset vaan niiden kautta näyttäytyvä kuva työtilanteiden ominaisuuksien yhteydestä kielelliseen vaativuuteen (Alastalo \& Åkerman, 2010).

Kielellisen suoriutumisen merkityksen näkee selkeimmin ns. korkean riskin aloilla, joilla kommunikoinnin onnistumisella on ratkaisevaa merkitystä ihmisten turvallisuudelle, kuten esimerkiksi ilmailualalla ja terveydenhuoltoalalla (Craig, Moxey, Young, Spenceley \& Davidson, 2012). Tämän tutkimuksen kontekstiksi on valittu terveydenhuolto, jonka toimintaa leimaa vahva potilaskeskeisyys ja jonka työkäytänteet määrittyvät pitkälti potilaan hyvinvoinnin ja turvallisuuden varmistamisen kautta (Vuori, 2013, s. 88). Yksi keskeisimmistä terveydenhuollon ammateista on lääkäri, joka on ylimmässä hoitovastuussa potilastyössä. Lääkäri työskentelee niin ruohonjuuritasolla potilaiden ja hoitohenkilökunnan kanssa kuin organisaatiotasollakin, hallinnon ja eri alojen viranomaisten kanssa. Lääkärin työnkuva on muuttunut viime vuosikymmenien aikana lääkäri- ja sisältökeskei- sestä potilaskeskeiseksi (Street, 2003, s. 912; Kurtz, Silverman \& Draper, 2005, s. 54). Lääkärin työ on julkista palvelua, mikä tarkoittaa, että lääkärin on kyettävä toimimaan kaikenlaisten ihmisten kanssa, iästä, sosiaalisesta ja kulttuuritaustasta sekä terveydentilasta riippumatta. Toiminta koskettaa perustavanlaatuisella tavalla ihmisen henkeä ja terveyttä, ja siksi kommunikoinnin epäonnistumisella voi olla vakavat seuraukset (Craig ym., 2012; Pöyri, Kóllar, Karukivi \& Haapasalo-Pesu, 2014; Tervola, 2017). Lisäksi lääkärin työ sisältää monella tavalla vaihtelevia työtilanteita ja tehtäviä, mikä vaatii lääkäriltä joustavuutta ja kykyä mukautua tilanteen vaatimuksiin (Kurtz ym. 2005, s. 54). Lääkärin työ tarjoaa siten hedelmällisen kontekstin työtilanteiden ominaisuuksien ja kielellisen vaativuuden yhteyden tarkastelulle.

Käsillä oleva artikkeli pohjautuu aiemmin julkaistuun tutkimukseen, jossa selvitettiin, miltä maahanmuuttajataustaisten lääkärien kielitaito vaikuttaa työelämän kannalta (Tervola, 2017). Tässä artikkelissa kohdistetaan huomio aiemmassa tutkimuksessa löydettyihin työtilanteiden ja kielellisen suoriutumisen välisiin yhteyksiin, analysoidaan niiden perusteella työtilanteiden ominaisuuksia ja muotoillaan niistä työtilanteille kriteereitä.

Tutkimus vastaa siis seuraaviin kysymyksiin:

- Mitkä työtilanteen ominaisuudet ovat yhteydessä maahanmuuttajataustaisen lääkärin kielelliseen suoriutumiseen tai suoriutumisongelmiin?

- Millaisia kriteereitä työtilanteille näistä ominaisuuksista voidaan johtaa?

Kriteerit luodaan yhdistelemällä ja erittelemällä löydettyjä ominaisuuksia siten, että ne ovat mahdollisimman yleispäteviä ja sovellettavissa siten tarpeen mukaan myös laajemmin eri alojen ja ammattien kielellisen vaativuuden mallintamiseen (kriteerien abstrahoinnista ks. Elder \& McNamara, 2016; Pill, 2016). 


\section{Ammatillinen kielitaito ja erityisalan kielitaito}

Erityisalan kielitaito määritellään usein työtilanteiden kautta. Esimerkiksi Härmälä (2008, s. 64) ja Virtanen (2017, s. 80) määrittelevät sen kykynä selviytyä kyseiseen alaan kuuluvista tilanteista. Erityisalojen kielentutkimuksessa lähtökohtana on ollut havainto, että kielenkäyttö vaihtelee eri aloilla ja ammateissa, mikä tarkoittaa, että erilaiset kielenainekset ja taidot ovat relevantteja eri aloilla (Hutchinson \& Waters, 1987, s. 21; Douglas, 2000, s. 7; Hyland \& Hamp-Lyons, 2002; Jäppinen, 2010, s. 13). Tästä näkökulmasta tarkasteltuna erityisalan kieli ei siis ole erillinen yleiskielestä tai muiden alojen kielestä oleva alue vaan se määrittyy lähestymistavan kautta, jossa alalle keskeiset kielenainekset ja taidot johdetaan erityisalan toimintaa ja kommunikointia havainnoimalla ja analysoimalla (Hutchinson \& Waters, 1987, s. 18-19; Douglas, 2000, s. 11). Erityisalan kieli ei siis rajoitu vain alan omaan käsitteistöön ja fraaseihin vaan kattaa runsaasti myös samoja aineksia yleiskielen tai muiden alojen kielen kanssa.

Erityisalojen kielen sisällä voidaan rajata eri tavoin sekä eri yhteyksiin ja ympäristöihin kohdennettua kielikoulutusta ja -testausta. Ammattikohtaisen kielikoulutuksen ja -testauksen tavoitteena on tuottaa ennustuskykyistä ja yleistettävissä olevaa tietoa yksilön edellytyksistä pärjätä tietyssä ammatissa (Byrnes, 2002a; Hutchinson \& Waters, 1987; Hyland, 2002). Tietyn koulutuksen suorittanut tai testin läpäissyt henkilö siis suoriutuu muita todennäköisemmin tietyn ammatin kielenkäyttöä vaativissa tehtävissä. Erityisalojen kieleen liittyvä tutkimus- ja kehitystyö keskittyy yhä useammin ammatti-ja alakohtaisen kielikoulutuksen ja -testauksen validointiin: tavoitteena on, että niiden tuottama tieto yksilöstä olisi mahdollisimman luotettavaa (Byrnes, 2002a, s. 55; Elder ym. 2013, s. 66).
Ennustuskyky ja yleistettävyys perustuvat ammattikasvatuksesta peräisin olevaan ajatukseen, että yksilöä koskevan tiedon analysointia varten täytyy kontrolloida ympäristön vaikutus (Johns, 2006, s. 403; Meyer, 2009, s. 69-70). Taustalla on sosiaalipsykologinen lähtökohta, jonka mukaan ihmisen käyttäytymistä ohjaavat sekä henkilökohtaiset ominaisuudet ja kyvyt että ympäröivät olosuhteet (Edwards \& Templeton, 2005, s. 706). Kun esimerkiksi opetustilanteeseen tuodaan elementtejä autenttisesta työympäristöstä, se auttaa ennakoimaan opetustilanteen ulkopuolella eteen tulevia haasteita (Byrnes, 2002a, s. 55; Tarnanen ym., 2007). On kuitenkin hyvä muistaa, että ennustusten ja yleistysten tekeminen on aina likimääräistä (Johns, 2006). Yksilön kielitaito, olosuhteet ja tilanteet sekä niiden välinen vuorovaikutus ovat hyvin moninaisia ilmiöitä, eikä ole mahdollista kontrolloida kaikkia suoriutumiseen vaikuttavia tekijöitä. Yleistyksien tekeminen on kuitenkin tarpeellista, jotta erilaisilla koulutuksilla ja testeillä olisi informaatioarvoa oppilaitoksille, työnantajille ja yksilöille itselleen.

\section{Tilanne analyysin kohteena}

Tilanteen käsitettä käytetään monilla aloilla ajallisen ja olosuhteiden vaihtelun kuvaamiseen. Esimerkiksi semantiikassa tilanteen (event) avulla pilkotaan havaintotodellisuutta kielennettäviksi yksiköiksi (Saeed, 2005, s. 117). Soveltavilla aloilla tilanteen käsitettä käytetäänkin tavallisesti todellisuuden jakamiseen osiksi tarkastelua varten, kun tutkitaan esimerkiksi ympäristön vaikutusta ihmisen toimintaan (Johns, 2006). Tilanne on siis eräänlainen abstraktio tai malli todellisuudesta, joka toimii linkkinä vaihtelevien olosuhteiden ja ihmisen välillä (Byrnes, 2002a, s. 55).

Tämä tutkimus liittyy lähinnä ammattikasvatuksen alaan, jossa esimerkiksi Meyer 
(2009, s. 13) on määritellyt työtilanteen seuraavasti:

[W] lork situations are combinations of people, objects, actions, general circumstances, and specific physical/social/psychological conditions surrounding a particular activity, occurring at a specific point in time, in a work-relevant context.

Määritelmä tuo esiin monia työtilanteen ulottuvuuksia ja korostaa siten työtilanteen käsitteen monitahoisuutta. Se on väljä ja siten sovellettavissa erilaisiin konteksteihin ja operationalisointitarkoituksiin. Kielitaitoon liittyvissä tutkimuksissa on määritelty pedagogisten tehtävien (task) ominaisuuksia ja niiden suhdetta kielellisen suorituksen tasoon ja laatuun (Skehan, 1996; Robinson, 2001; Härmälä, 2008). Ne ovat oppitunneilla käytettäviä tehtäviä, joiden laadinnassa voidaan huomioida erilaisten ominaisuuksien vaikutuksia. Skehanin (1996, s. 38) määritelmän mukaan tehtävä (task) on toimintaa, jossa funktio ${ }^{1}$ on etualalla, jossa on jonkinlainen suhde todellisuuteen ja jota voidaan arvioida sen tulosten perusteella. Tässä tutkimuksessa käytän pohjana Skehanin ja Meyerin määritelmiä ja määrittelen työtilanteen ammattikontekstiin kuuluvana kommunikointitilanteena siten, että työtilanne on käytännön työssä toistuvasti vastaan tuleva ajallisesti ja paikallisesti erottuva jakso, jolla on työn kannalta jokin selkeä funktio, jonka toteutumista voi arvioida onnistuneisuuden mukaan ja jonka toteutumisessa kommunikoinnilla on rooli. Määritelmä ei tarjoa yleispätevää ohjetta, kuinka todellisuutta

1 Skehan (1996: 38) käyttää tarkalleen ottaen ilmaisua "merkitys" (meaning) kontrastoidakseen sen muotokeskeiseen pedagogiikkaan nähden. Käsittääkseni hän ei kuitenkaan viittaa merkitykseen semanttisena sisältönä vaan nimenomaan tilanteen funktiona. tulisi jakaa osiin, mikä mahdollistaa käsitteen soveltamisen erilaisissa ympäristöissä ja eri tarkoituksissa eri tavoin. Työtilanteiden analyysi ei nähdäkseni voikaan tarjota yhtä oikeaa ratkaisumallia vaan on pikemminkin lähestymistapa työympäristön ja yksilön välisen vuorovaikutuksen tutkimiseen.

Työtilanteita voi analysoida esimerkiksi tilanteen tavoitteiden, osallistujien roolien ja sitä määrittävien sääntöjen kautta (Hargie, 2006b, s. 60). Analysoidut ominaisuudet ovat usein jatkumoluonteisia, esimerkiksi muodollinen-epämuodollinen, ylläpitoorientoitunut-muutosorientoitunut (Meyer, 2009, s. 62) tai kategorialuonteisia kuten osallistujien roolit ja ikä (Hargie, 2006b, s. 60) tai tilanteen rutiinimaisuus ja kiireellisyys (Berger, 2003). Lisäksi joitakin yksittäisiä tilannetyyppejä voidaan käsitellä syvemmin, esimerkiksi ryhmätilanteita (Wit, 2006). Jaottelun moninaisuudesta näkyy, että tilanne itsessään on moniulotteinen ilmiö, johon liittyvä tieto on hajallaan eri tieteenaloilla ja tutkimussuuntauksissa. Tämän tiedon yhdistäminen ja esittäminen käyttökelpoisessa muodossa on kuitenkin tarpeellista soveltavissa tutkimussuuntauksissa (Rowan, 2003, s. 408). Se on myös tämän tutkimuksen yksi tavoite.

Työtilanteiden ominaisuuksia on analysoitu kielellisen suoriutumisen näkökulmasta vain vähän (ks. kuitenkin Byrnes, 2002b). Kielenopetuksessa sen sijaan on tunnettua, että harjoitustehtävien ominaisuudet voivat nostaa kielellistä vaatimustasoa tai edellyttää laadultaan erilaista kielitaitoa (Skehan, 1996; Robinson, 2001; Iwashita, McNamara \& Elder, 2001; Cormier, McGrew \& Evans, 2011). Esimerkiksi kompleksinen tehtävä tuottaa sujuvuudeltaan heikompaa mutta toisaalta leksikaalisesti rikkaampaa kieltä kuin yksinkertainen tehtävä (Robinson, 2001, s. 52). Tehtävien vaativuuteen vaikuttavia tekijöitä ovat muun muassa suorituksen suunnitteluun 
käytettävissä oleva aika, tehtävän muodostuminen useammasta osasuorituksesta, tehtävän tuttuus, päättelyn vaatimus ja käsiteltävän informaation abstraktioaste (mts. 38; Skehan, 1998, s. 174). Vuorovaikutuksen luonteeseen liittyviä tekijöitä ovat esimerkiksi osallistujien määrä, osallistujien väliset suhteet ja roolit, vuorovaikutuksen suunta ja ennakoitavuus (Robinson, 2001, s. 30, 32-33). Tehtävien ominaisuuksien määrittely perustuu siihen, kuinka erilaiset tehtävien ominaisuudet lisäävät kielelliseen prosessointiin liittyvää kognitiivis-psykologista kuormitusta (mts. 31).

Erityisalojen kielentutkimuksessa on kuitenkin myös kyseenalaistettu, missä määrin työtehtävän suorittamisen kannalta on merkitystä, kuinka sujuvaa tai kompleksista työtilanteessa käytetty kieli on (Elder, McNamara, Kim, Pill \& Sato, 2017). On helppo ajatella, että tv-juontajan työssä puheen sujuvuus on olennainen tekijä mutta lääkärin selittäessä potilaalle elintärkeän hoidon merkitystä ja kulkua sujuvuudella ei ole niin suurta merkitystä kuin vaikkapa merkityksen tarkkuudella ja selkeydellä. Mitään yleispätevää kielellisen suoriutumisen standardia ei siis voida määrittää, ja siksi kielellistä suoriutumista arvioitaessa onkin syytä käyttää mittapuuna alan omasta toiminnasta nousevia kriteereitä (Elder \& McNamara, 2016; Huhta, Jaatinen ym. 2006, s. 51; Pill \& McNamara, 2016). Työtilanteilla on aina jonkinlainen alan toimintaan liittyvä tavoite, johon toiminnan tulosta ja siten myös kielellistä suoriutumista voidaan suhteuttaa (Rowan, 2003, s. 408). Tämä on erityisalojen kielitaidon opetuksen ja tutkimuksen validiuden edellytys ja siten koko tutkimusalan tärkeimpiä olemassaolon oikeutuksia. Tässä tutkimuksessa huomio kohdistuu juuri siihen, millaisissa työtilanteissa kielellinen suoriutuminen on onnistunut tai epäonnistunut alan omien toiminnallisten kriteerien mukaan.

\section{AINEISTO JA METODI}

Tässä tutkimuksessa työtilanteiden ominaisuuksia analysoitiin haastatteluaineistosta, jossa haastateltavat puhuivat lääkärin työtilanteista sekä maahanmuuttajataustaisten lääkärien kielellisestä suoriutumisesta niissä. Haastattelut toteutettiin puolistrukturoituina fokushaastatteluina (ks. Merton, Fiske \& Kendall, 1990). Niihin valittiin Tampereen yliopiston lääketieteen kouluttajien sekä yhteistyölaitosten yhteyshenkilöiden asiantuntemuksen avulla tutkimuksen aiheen kannalta edustavia henkilöitä, joilla on kokemusta suomalaisissa sairaanhoidon ja terveydenhuollon laitoksissa työskentelystä sekä maahanmuuttajataustaisten lääkärien kanssa työskentelystä. Haastattelujen edustavuus varmistettiin siten, että mukaan otettiin erilaisia julkisen sektorin laitoksia ja haastatteluun kutsuttiin terveydenhuollon eri ammattikuntia ja erilaisia osastoja edustavia henkilöitä. Haastateltavia oli yhteensä 32 ja haastattelutilaisuuksia 6. Haastattelut järjestettiin Etelä-, Itä- ja Länsi-Suomen alueilla vuoden 2015 aikana. Taulukossa 1 on eriteltynä laitosten tyyppi, haastateltavien määrä ja ammattiala kussakin laitoksessa.

Haastatteluiden tarkoituksena oli selvittää, miltä maahanmuuttajataustaisten lääkärien suomen kielen taito vaikuttaa työn vaatimusten ja työyhteisön toiminnan kannalta. Tämän artikkelin kannalta olennaisia ovat haastattelun osiot, joissa kysyttiin, missä työtilanteissa haastateltavat ovat mahdollisesti kohdanneet kielitaidon puutteellisuudesta johtuvia ongelmia ja kuinka usein he ovat kohdanneet vakavuudeltaan eriasteisia ongelmia (merkityksettömiä, pienellä vaivalla selvitettäviä tai vakavia, joissa potilaan hoito vaarantuu tai kärsii). Lisäksi haastatteluissa keskusteltiin toimenpiteistä, joita työyhteisöt ovat kehittäneet, sekä tarpeista, joita työyhteisöillä on kielitaito-ongelmien hallintaan 
Taulukko 1. Laitosten tyyppi, haastateltavien määrä ja ammattiala. 32 haastateltavan jou. kossa on 26 naista ja 6 miestä, joista 4 lääkäriä ja 2 hoitajaa. Suluissa on esimiestehtävissä toimivien määrä.

\begin{tabular}{|l|l|l|l|l|l|l|}
\hline \multirow{2}{*}{$\begin{array}{l}\text { Laitoksen } \\
\text { numero }\end{array}$} & Laitoksen tyyppi & \multicolumn{6}{l}{ Haastateltavien ammattiala } \\
\cline { 3 - 8 } & & Lääkärit & Hoitohenkilökunta & Sihteerit & Muut & Yhteensä \\
\hline 1 & Terveyskeskus & $2(1)$ & 3 & - & - & $5(1)$ \\
\hline 2 & Terveyskeskus & $2(1)$ & 3 & 1 & - & $6(1)$ \\
\hline 3 & Kaupunginsairaala & $2(1)$ & $2(1)$ & 1 & - & $5(2)$ \\
\hline 4 & Kaupunginsairaala & $1(1)$ & $3(1)$ & 1 & $1^{*}$ & $6(2)$ \\
\hline 5 & $\begin{array}{l}\text { Psykiatrinen } \\
\text { sairaala }\end{array}$ & $1(1)$ & $3(1)$ & 1 & - & $5(2)$ \\
\hline 6 & Keskussairaala & - & $4(2)$ & - & $1^{* *}$ & $5(2)$ \\
\hline YHTEENSÄ & & $8(5)$ & $18(5)$ & 4 & 2 & $32(10)$ \\
\hline
\end{tabular}

* Fysioterapeutti, ** Palvelukoordinaattori

liittyen. Niistä sekä työyhteisöjen yleisestä näkökulmasta mahdollisiin kielitaito-ongelmiin on raportoitu aiemmassa julkaisussa (Tervola, 2017).

Käsillä olevan tutkimuksen tarpeisiin aineisto analysoitiin siitä näkökulmasta, millaiset tilanteiden ominaisuudet aineistossa yhdistyvät koettuihin kielellisen suoriutumisen ongelmiin. Sisällönanalyysissa aineistosta eriteltiin kaikki tekijät, joita haastateltavat käyttivät kertoessaan erilaisiin työtilanteisiin liittyvistä kielitaito-ongelmista (vrt. Hirsijärvi \& Hurme, 2014). Nämä tekijät muotoiltiin koodeiksi ja luokiteltiin (taulukko 2). Analyysin luotettavuuden vahvistamiseksi koodaus ja luokittelu tarkistettiin kielentutkijoiden työpajassa. Koodit eivät ole keskenään symmetrisiä eivätkä kata luokkien kaikkia piirteitä vaan pohjautuvat siihen, mitä haastateltavat ovat haastattelussa sanoneet. Koodit kuvaavat esimerkiksi tilanteita, tilanteen osallistujia ja tilanteen ominaisuuksia. Koodien avulla eri tavoin ilmaistut mutta samaan asiaan viittaavat puheenvuorot saatiin yhdistettyä (samaan tapaan kielellisen suoriutumisen laatua on analysoinut tutkimuksessa Pill, 2016). Esimerkiksi koodi TyÖN LISÄÄNTYMINEN liitettiin analyysissa seuraavanlaisiin konkreettisiin ilmauksiin aineistossa:

"et se on moninkertainen työ, varsinki siinä alkuvaiheessa"

"aiheuttaa monelle työtä"

"hankaloittaa muiden työtä ja lisää semmosta, lisätyötä tekee, pitää varmistella sitte, tiedustella undestaan"

Kunkin koodin sisältämiä aineisto-otteita tarkasteltiin erikseen, jotta saatiin näkyviin koodin merkitsemän ilmiön laajuus ja luonne sekä sen suhde kielelliseen suoriutumiseen. Analyysin tulokset esitellään koodeittain, minkäjälkeen tehdään yhteenveto esiin nousseista yhteyksistä.

\section{ANALYYSIN TULOKSET}

Analyysissa nousi esiin useita työtilanteisiin liittyviä ominaisuuksia, jotka ovat yhteydessä maahanmuuttajataustaisten lääkärien kielelliseen suoriutumiseen tai suoriutumisongelmiin. Analyysi esitetään siltä kannalta, miten työtilanteiden ominaisuudet nostavat kielitaidon vaatimustasoa suhteessa sellaiseen 
Taulukko 2. Sisällönanalyysin koodit. Osa analyysikoodeista on peräisin haastattelukysymyksistä, osan taas haastateltavat ovat itse tuoneet esiin haastattelutilanteessa.

\begin{tabular}{|c|c|c|c|c|c|c|}
\hline \multirow{2}{*}{$\begin{array}{l}\text { Luokka } \\
\text { Osallistujat }\end{array}$} & \multicolumn{6}{|c|}{ Analyysikoodit } \\
\hline & $\begin{array}{l}\text { Lääkäri- } \\
\text { lääkäri }\end{array}$ & $\begin{array}{l}\text { Lääkäri- } \\
\text { hoitaja }\end{array}$ & $\begin{array}{l}\text { Lääkäri- } \\
\text { esimies }\end{array}$ & $\begin{array}{l}\text { Lääkäri- } \\
\text { potilas }\end{array}$ & $\begin{array}{l}\text { Lääkäri- } \\
\text { omaiset }\end{array}$ & $\begin{array}{l}\text { Lääkäri- } \\
\text { viranomaiset }\end{array}$ \\
\hline $\begin{array}{l}\text { Erilaiset } \\
\text { potilaat }\end{array}$ & Vanhukset & \begin{tabular}{|l|} 
Mielenter- \\
veyspotilaat
\end{tabular} & $\begin{array}{l}\text { Alzheimer- } \\
\text { potilaat }\end{array}$ & & & \\
\hline Potilaan tila & Huono kuulo & $\begin{array}{l}\text { Jännitys, } \\
\text { ahdistus }\end{array}$ & $\begin{array}{l}\text { Negatiivinen } \\
\text { asenne }\end{array}$ & & & \\
\hline Tilanteet & \begin{tabular}{|l} 
Potilas- \\
vastaanotto
\end{tabular} & Potilaskierto & $\begin{array}{l}\text { Kollegan } \\
\text { konsultointi }\end{array}$ & $\begin{array}{l}\text { Kokoukset } \\
\text { ja palaverit }\end{array}$ & $\begin{array}{l}\text { Epäviralli- } \\
\text { set tilan- } \\
\text { teet }\end{array}$ & \\
\hline Tekstit & Sähköpostit & $\begin{array}{l}\text { Potilasasia- } \\
\text { kirjat }\end{array}$ & Lausunnot & Lähetteet & Ohjeet & $\begin{array}{l}\text { Laki- ja } \\
\text { säädös- } \\
\text { tekstit }\end{array}$ \\
\hline $\begin{array}{l}\text { Tilanteiden } \\
\text { ominai- } \\
\text { suudet }\end{array}$ & $\begin{array}{l}\text { Kanava } \\
\text { - kasvokkain } \\
\text { - etäyhteys }\end{array}$ & $\begin{array}{l}\text { Akustiset } \\
\text { - kaiku } \\
\text { - häly }\end{array}$ & $\begin{array}{l}\text { Sosiaaliset } \\
\text { - tuttuus } \\
\text { - ryhmä- } \\
\text { tilanteet }\end{array}$ & Aika & $\begin{array}{l}\text { Kollegan } \\
\text { tuki }\end{array}$ & Uusi tilanne \\
\hline $\begin{array}{l}\text { Kielelliset } \\
\text { tekijät }\end{array}$ & $\begin{array}{l}\text { Puhe } \\
\text { - tuotto } \\
\text { - ääntäminen } \\
\text { - ymmärtä- } \\
\text { minen } \\
\text { - eleet ja } \\
\text { ilmeet }\end{array}$ & $\begin{array}{l}\text { Kirjoitus } \\
\text { - tuotto } \\
\text { - oikein- } \\
\text { kirjoitus } \\
\text { - lukeminen }\end{array}$ & \begin{tabular}{|l|} 
Kielioppi \\
- rakenteet \\
- sanajärjes- \\
tys \\
- taivutta- \\
mattomuus
\end{tabular} & $\begin{array}{l}\text { Sanasto } \\
\text { - sävyerot } \\
\text { - vertaus- } \\
\text { kuvat } \\
\text { - sanonnat } \\
\text { - huumori }\end{array}$ & $\begin{array}{l}\text { Abstraktio- } \\
\text { taso }\end{array}$ & $\begin{array}{l}\text { Monitulkin- } \\
\text { taisuus }\end{array}$ \\
\hline $\begin{array}{l}\text { Kielitaidon } \\
\text { puutteiden } \\
\text { seuraukset }\end{array}$ & $\begin{array}{l}\text { Väärä } \\
\text { diagnoosi } \\
\text { /hoito }\end{array}$ & $\begin{array}{l}\text { Viivästynyt } \\
\text { diagnoosi/ } \\
\text { hoito }\end{array}$ & $\begin{array}{l}\text { Työ lisään- } \\
\text { tyy } \\
\text { - uusi } \\
\text { vastaan- } \\
\text { ottoaika } \\
\end{array}$ & $\begin{array}{l}\text { Vaara- } \\
\text { tilanne }\end{array}$ & $\begin{array}{l}\text { Ahdistus, } \\
\text { epävar- } \\
\text { muus }\end{array}$ & $\begin{array}{l}\text { Hoitajien } \\
\text { suuri vastuu }\end{array}$ \\
\hline $\begin{array}{l}\text { Epävarmuu- } \\
\text { den merkit }\end{array}$ & \begin{tabular}{|l|} 
Tekstien \\
kopioiminen
\end{tabular} & \begin{tabular}{|l|} 
Hiljaisuus, \\
kantaaotta- \\
mattomuus
\end{tabular} & \begin{tabular}{|l|} 
Ymmärtämät- \\
tömyyden \\
piilottaminen
\end{tabular} & $\begin{array}{l}\text { Tilanteiden } \\
\text { välttely }\end{array}$ & & \\
\hline
\end{tabular}

työtilanteeseen, josta kyseinen ominaisuus puuttuu. Ominaisuudet esitellään tässä jaoteltuna kolmeen ryhmään: tilanteen seurauksiin liittyvät, tilanteen osapuoliin liittyvät ja muut tilanteisiin liittyvät ominaisuudet.

\section{Työtilanteen seuraukset}

Yksi eniten esillä olleista näkökulmista oli työtilanteen seuraukset. Tämä teema sisältyi jo haastattelukysymyksiin mutta haastateltavat puhuivat seurauksista paljon myös omaaloitteisesti haastattelun muissa osioissa. Tavallisimpina seurauksina mainittiin lisäänty- nyt työ, epävarmuus niin henkilökunnan kuin potilaidenkin keskuudessa sekä hoitohenkilökunnan lisääntynyt vastuu. Haastateltavat tunnistivat vakavuudeltaan eritasoisia seurauksia ja erottivat esimerkiksi potilaan henkeä ja terveyttä uhkaavat seuraukset muista vähemmän vakavista seurauksista, joita ovat esimerkiksi työmäärään liittyvät seuraukset, psyykkiseen kuormitukseen liittyvät seuraukset ja potilaille tai työyhteisölle aiheutuvat seuraukset (ks. tarkemmin Tervola, 2017). Seuraavat aineistoesimerkit on poimittu seurauksia kuvaavien koodien (TYÖN LISÄÄNTYMINEN, EPÄVARMUUS, VAARATILANNE 
jne., ks. taulukko 2) perusteella:

Ja kyllä näissä lausunnoissa luvattoman usein on ihan asiavirheitä, sen takia et ku ei tunne lauserakenteita oikein, niin sitte yks lause voi tarkottaa kahta asiaa. Mut onneks ne nyt palautuu usein sitte, ja eibän ne nyt sit potilaan benkeä ubkaa, ne lausunnot, ne on vaan ikäviä korjata, aiheuttaa monelle työtä, sit kun niitä palautellaan tuolla pitkin maailmaa, maistraatista tai mistä sitten tuleekaan tai Kelalta, et ei he ymmärrä tästä, et työtähän se teettää.

[LAUSUNNOT, LÄÄKÄRI-VIRANOMAISET, Rakenteet, Monitulkintaisuus, TYÖN LISÄÄNTYMINEN; KS2-L2] 2,3

Toisessa työpaikassa kun itse hoidin päivystystä, niin tulee sellaset, jotka on käyny samana päivänä lääkärillä tai edellisenä päivänä päivystyksessä, mutta kun ne eivätymmärtäneet tai ei tullut asia selväks, niin ne tulevat sitten uudestaan, kun tulee suomalainen lääkäri, että onhan ne nyt siinä mielessä jossain määrin vaarallisiakin, että potilas ei oo tajunnut, mitä hänen pitää tehdä.

[PotilasvastaANOTTO, LÄÄKÄRI-POTILAS, UUSi VASTAANOTTOAIKA, EpäVARMUUS; TK1-L8]

\section{Pubelinmääräykset on mun mielestä tosi vaarallisia, elikkä ne pitää saada kirjalli- sina. \\ [Puhelinkeskustele, LäÄKäRI-HOI- TAJA, VAARATILANNE; KES-H1]}

2 Aineistositaatteja on muokattu yleiskielisempään suuntaan lukemisen helpottamiseksi.

3 Hakasulkeisiin on merkitty jakson sisältämät analyysikoodit (ks. taulukko 5) sekä puhujan ja hänen edustamansa instituution identifiointitunnus. Tunnuksissa käytetään seuraavia lyhenteitä: $\mathrm{KS}=$ kaupunginsairaala, KES=keskussairaala, PS=psykiatrinen sairaala, TK=terveyskeskus; $\mathrm{H}=$ hoitohenkilö, $\mathrm{L}=$ =ääkäri, $S=$ sihteeri, $M=$ muu.
Korkean riskin aloilla kuten terveydenhuollossa osa työtehtävistä on mahdollisten seurausten kannalta vakavia. Tällaisissa tilanteissa kommunikoinnin onnistuminen on ratkaiseva tekijä (Reader, Flin \& Cuthbertson, 2007; Brindley \& Reynolds, 2011; Craigym., 2012). Seuraukset eivät itsessään tee tilanteesta kielellisesti vaikeaa, mutta ne kertovat, kuinka välttämätöntä tilanteessa on suoriutua kielellisesti hyvin: jos tilanteessa on potilaan henki kyseessä, kommunikoinnin onnistuminen on välttämätöntä, mikä asettaa tiukan vaatimuksen myös työntekijöiden kielitaidolle. Mitä vakavammat potentiaaliset seuraukset tilanteella on, sitä tiukempi tulee olla myös kielitaitovaatimus niillä, joiden työnkuvaan kyseiset tilanteet kuuluvat.

\section{Työtilanteen osapuoliin liittyvät ilmiöt}

Lähes kaikki haastateltavat vertailivat kielellistä suoriutumista sen mukaan, keitä työtilanteessa on mukana. Tilanteen osallistujilla nähtiin olevan suurta merkitystä sille, miten hyvin maahanmuuttajataustainen lääkäri pärjää tilanteessa kielellisesti. Monissa haastatteluissa huomautettiin, että maahanmuuttajataustaisen lääkärin on helpointa keskustella toisen lääkärin kanssa muun muassa kansainvälisen lääketieteellisen terminologian ansiosta. Myös muiden terveydenhuollon ammattilaisten kanssa keskustelua pidettiin suhteellisen ongelmattomana, joskin sen katsottiin vaativan jo hieman monipuolisempaa kielitaitoa. Potilaiden ja omaisten kanssa keskusteluissa sen sijaan nähtiin paljon ongelmia, ja niiden katsottiin vaativan vahvaa kielitaitoa. Seuraavat esimerkit havainnollistavat, miten haastateltavat vertailevat työtilanteita osallistujien kannalta:

En niinkä̈̈n olis huolestunu tästä sanaston niukkuudesta. Se voi olla niukka mut sit lä̈ketieteellinen termistö on usein 
hallinnassa jollain tapaa, et se ei niin haittaa siinä lääkäreiden välillä kun käydään keskustelua. Mut ei se sit varmaan sitäpotilasta lohduta, kun se ei tunne lä̈ketieteellistä sanastoa.

[LÄÄKÄRI-LÄÄKÄRI, LÄÄKÄRI-POTILAS, SANASTO; KS1-L2]

Jos ajatellaan ihan moniammatillisen $y b$ teistyön näkökulmasta, ni jos se ammattisanasto on ainoo mitä on, et niitä yksittäisii sanoi tulee, ni kylse semmonen lääkärin tuki mitä hoitohenkilökunta jafysioterapiassaki tarvii, ni jos sielt ei tuu sitä tukea, ni se ymmärrysjääpuutteelliseks. Nimonessakin kohtaa sit hankaloittaa ja ei ainakaan sen työn sujuvuutta edesauta. [-] Et kyl sit kuitenki pitää osata kertoamonisanaisemmin, että mitä on aikomus lääkärin esimerkiks tutkia ja mitäpäätöksiä hän on tehny ja mitä hän tulkitsee tästä tuloksesta ja miten se sit vaikuttaa esimerkiks hoitotyön ratkasuibin. [LÄÄKÄRI-KOLLEGA, KOLlEGAN TUKI, Ammattitermit; KS1-H10]

Meilkorostuu se potilaan ja lääkärin kohtaaminen. Potilaat eivät ymmärrä, ja hoitajat pystyy tarkentavia kysymyksiä tekemään, joutuvat tekemään, jotta pystyvät ammatillisesti toimimaan, ettei tule lääkintä-tai muita virheitä. Ja potilaat ei siinä kiireessä pysty kysymään, kun lääkäri on jo mennyt pois. Eli potilaat jä̈uät heikommalle kuin hoitajat, kielellisesti.

[LÄÄKÄRI-POTILAS, LÄÄKÄRI-HOITAJA; KES-H2]

Analyysin tulosta on syytä tulkita siitä näkökulmasta, että maahanmuuttajataustaisella lääkärillä on eniten jaettua tietoa ja samankaltaisia käsityksiä toisen lääkärin kanssa. Tulos heijastaa kommunikoinnin ja ymmärtämisen yleistä lainalaisuutta, jonka mukaan yhteinen tietopohja tukee keskinäisen ymmärryksen muodostumista (Krauss \& Fussell, 1990; Shapiro, 2004). Samanlainen koulutustausta mahdollistaa suuren määrän yhteistä tietoa, joka helpottaa lääkärien välistä keskustelua. Yhteinen työympäristö ja kokemukset vahvistavat yhteistä tieto- ja käsityspohjaa myös muiden terveydenhuollon ammattilaisten kanssa (Eraut, 1994, s. 87). Potilaiden ja omaisten tiedot ja käsitykset taas vaihtelevat paljon, ja lääkäri voi joutua näkemään vaivaa yhteisymmärryksen muodostamiseksi (Kurtz ym. 2005, s. 54; Brown, 2006, s. 213).

Yhdessä haastattelussa nostettiin samasta näkökulmasta esiin luetun ymmärtäminen; lääketieteellisten aiheiden katsottiin olevan helpompia ymmärtää muihin terveydenhuoltoon liittyviin aiheisiin verrattuna.

Tämmönen lakiteksti on ilmeisesti näille lä̈käreille aika vaikea ymmärtää. Et ihan pubtaasti tämmönen lääketieteellinen teksti, ni he ymmärtä̈, mut tämmönen muunlainen teksti, vaikka työhyvinvointiin liittyen, joku päihdeongelmavibko, ni se on vaikeaa. Et sit ku kysyy, että mitä mieltä sinä olet asioista, ni he pubuvat aivan eri asiasta kuin mistä se tekstin sisältö oikeastaan on.

\section{[LUKEMINEN, LAKITEKSTIT; KES-H3]}

Luetun ymmärtämisen tutkimuksessa on taustatiedon merkitys tunnettu hyvin. Taustatiedoilla saattaa olla jopa kielitaitotasoa suurempi merkitys ymmärtämisessä (Johnson, 1982). Oman alan tekstissä erityisesti sanaston tuttuus on merkittävä ymmärrystä tukeva elementti (Hsueh-Chao \& Nation, 2000).

Kollegoiden tuen merkitys nousi haastatteluissa esiin usein. Haastateltavien mukaan kielellisen suoriutumisen kannalta on suuri merkitys sillä, onko lääkäri potilastilanteessa yksin vai onko hänen tukenaan kokeneempia ja kielitaitoisempia kollegoita. Seuraavat otteet aineistosta on poimittu koodin Kolle- 
GAN TUKI perusteella:

Meillä lääkärit ku he on valmiita lääkäreitä, ni he tapaa potilasta yksin, meil ei oo mahdollisuutta, et siel on hoitaja vastaanotolla mukana, koska hoitajat tapaa omia potilaitaan, kun lääärin vastaanotto pyörii. Siinä se suurin ongelma on, se potilaan kuuleminen.

[PotilasvastaAnOtTO, LäÄKÄRI-POTILAS, Kollegan TUKI; PS-S1]

Se mibin mä oon laittanu et usein tulee ongelmia, on just tää potilasvastaanotto, sen takii et mä en oo esimerkiksi itse siel sillon paikalla. Et ei musta [kollegoiden välisessä] kasvokkaiskonsultoinnissa tai raportoinnissa ikinä mitä̈n tai hyvin harvoin mitää ongelmii on, ku asiat keskustellaan näin ja useimmiten pystyy saamaa selvyyttä siihen tilanteeseen.

[PotilasvastaAnOtTo, LäÄKÄRI-POTILAS, LÄÄKÄRI-LÄÄKÄRI, KOLlEGAN TUKI; PS-L1]

Täytyy ihan oikeesti sanoa, että kyllähän tämmösen ulkomaalaistaustasen lä̈kärin paljon helpompi on toimia sairaalassa, jossa hoitajat on puskurina ja sen potilaan asianajajana, et pystyvät vähän, tai pystyvät hyvinkin arvioimaan, että mitä määräyksiä... ja meilläkin on hyvin koulutettu henkilöstö, esim. lä̈̈kehoidon osalta, mutta entäs sitte jos se onkin kabdestaan sen potilaan kanssa?

[LÄÄKÄRI-POTILAS, KOLlEgaN TUKI; KS1-L2]

Kollegoiden tuen merkitys kielenoppimiselle tunnetaan hyvin ammatillisen kielenoppimisen piirissä (Suni, 2011; Virtanen, 2017). Tämä analyysi osoittaa, että kollegoiden tuki mahdollistaa suoriutumisen sellaisissakin työtilanteissa, joista ilman tukea ei suoriutui- si hyvin. Onkin luultavaa, että juuri tämän laajemman osallistumisen ansiosta myös oppiminen edistyy. Toisaalta tulos osoittaa, että itsenäiseen työtehtävien suorittamiseen on tarpeen vaatia korkeampaa kielitaitoa.

Haastatteluissa tuli esiin myös tietyille potilasryhmille tyypillisiä kommunikointivaikeuksia kuten vanhusten aistiongelmien, Alzheimerin taudin sekä mielenterveysongelmien vaikutus potilaan kommunikointikykyyn. Lisäksi yleisen potilaiden keskinäisen erilaisuuden katsottiin luovan vaatimuksia lääkärille mukauttaa kielenkäyttöään potilaalle sopivaksi. Seuraavat otteet on valittu aineistosta koodien Mielenterveyspotilas ja ERILAISET POTILAAT perusteella:

Aika paljon tulee asiakkailta semmosta viestii, et ei häntä kuultu, ei häntä ymmärretty, mitä se mahto mulle sanoo, he soittaa ja sitten hoitohenkilö joutuu selvittää sitä jälkeenpäin, ettämitäsiel on pubuttu. - Ja sit tietysti kun on kyse psyykkisesti sairaista potilaista, ni se ulosanti on joskus hyvin erilaista.

[LÄÄKÄRI-Potilas, PUhe, YMmärtäminen, Mielenterveyspotilas; PSS1]

Siin on tietysti tämä näkökohta, että ku äidinkielellä on monta kertaa potilaan pubeen sisältöö vaikee ymmärtää, saatikka sitte psykoottisen potilaan pubeen sisältöö ymmärtää, saatikka sitte ku yrität vieraalla kielellä ymmärtää sitä. Ja sit se mitä se lääkäri vastaa, ni se potilas ei tuu ihan kohdatuksi sitte niissä asioissa kyllä.

[LäÄKÄri-Potilas, Puhe, YMmärtäminen, Mielenterveyspotilas; PSH7]

Siinä on tietenki varmaan ulkomaalaiselle lääkärille suuri haaste tässä, että hän pystyis arvioimaan, millasta kieltäpotilas ymmärtä̈. Et ei varmaan pysty mukautumaan 
sillai ku äidinkielenään suomea puhuva voi mukauttaa sitä omaa sanastoaan sen mukaan, et ymmärtääkö potilas vai ei ja voiko siirtyä vähän vaikeempaankin termistöön.

[LÄ̈̈KÄRI-POTILAS, ERILAISET POTILAAT, SANASTO; KS2-L6]

Myös jännitys ja stressi saattavat vaikuttaa potilaan kommunikointikykyyn, mikä niin ikään nostaa vaatimusta lääkärin kielenkäyttötaidolle. Tämä nousi esiin parissa haastattelussa:

Se voi itsessään olla se lääkärin kierto niin jännittävä tilanne potilaalle, et jos siin on suomalainenki lä̈käri, joka selittää, ni potilaalla menee helposti $80 \%$ asiasta obi. Sit ku siin on henkilö, jonka suomen kielen taito ei oo niin hyvä, ni sillä menee ne loputkin kaikki obi, ku se keskittää sen pinnistämisen siihen, et mitähän tää nyt niinku sano.

[PotilaskieRTo, LÄÄKÄRI-POTIlAS, JÄNNITYS; KES-H1]

Potilaiden moninaisten kommunikointikykyjen tuomat haasteet lääkärille on tunnustettu laajasti, ja niiden huomioimiseen ohjataan esimerkiksi alan oppikirjoissa (ks. esim. Kurtz ym., 2005; Lloyd \& Bor, 2009). Esimerkiksi stressin alaisena ihmisen kommunikointikykyjen on havaittu heikkenevän (Berger, 2003, s. 265). Potilaiden kommunikointikyvyn vaihtelu liittyy asetelmaan, jossa lääkäri on viranomaisen ja asiantuntijan asemassa ja siten vastuussa hoitotilanteesta, kun taas potilas on tilanteessa apua hakevana osapuolena. Lääkärin tulisi siis pystyä paikkaamaan potilaan mahdollisesti puutteellista kommunikointia (Kurtz ym., 2005, s. 178-183). Potilaiden kommunikointikykyyn mukautuminen edellyttää, että lääkärillä on useampia vaihtoehtoisia tapoja ilmaista samoja sisältöjä ja että hän pystyy arvioimaan niiden sopivuutta kunkin potilaan kommunikointikykyyn näh- den (mts. 89). Tämä kaikki nostaa lääkärin kielellisen suoriutumisen vaatimustasoa.

Myös työtilanteen osallistujien määrällä on haastateltavien mukaan merkitystä. Haastateltavat pitivät ryhmätilanteita kuten kokouksia ja palavereita maahanmuuttajataustaiselle lääkärille hankalampina kuin kahdenkeskistä konsultointitilannetta. Aineistoesimerkit on koottu koodin RYHMÄTILANNE perusteella:

Sitnääkokouksetja palaverit, et jos monipuhuu päällekkäin ja on vähän hälinää, niin kyllä sitä on vaikee seurata. Et varmaan se, et on palaverissa hiljaa, ni todennäköisesti johtuu siitä, et ei oikeen pysy kärryillä, et mistä täälläpuhutaan.

[Kokoukset Ja PAlaVerit, Häly, RYHmätilanne, HiljaisuUs; KS2-L6]

Kyllä varmasti niissä kokouksissa menee aika paljon ohi ymmärryksen. Et siellähän pubutaan aika nopeasti ja siel pubuu eri henkilöt aika erilaisella vaikka murteella, et se on aika vaikea maahanmunttajataustaiselle lä̈kärille seurata sitä kokousta. [--] Et sit ei enää pysy kärryillä, vaikka sitä ybtä pystyiski seuraamaan, mut sitten ku toinen antaa kommentin ni ei enää pystykään seuraamaan tekstiä.

[Kokoukset JA PALAVERIT, RYHMÄTILANNe, PuheEnymmärtäminen; KESH3]

Useampi osallistuja tekee kommunikointitilanteesta kompleksisemman (Gibson, 2003; Wit, 2006), mikä lisää sen haasteellisuutta kahdenkeskiseen kommunikointitilanteeseen verrattuna. Monesti ryhmätilanteessa myös yhteinen tietopohja on paljon kapeampi, jolloin osallistujat joutuvat näkemään enemmän vaivaa yhteisymmärryksen muodostamiseksi (Wit, 2006, s. 383). Tämä voi tuottaa erityisen suuria haasteita silloin, kun osallistujan kielitaito on heikompi kuin muiden. 
Yhtenä merkittävänä tilanteen osapuoliin liittyvänä tekijänä haastateltavat pitävät sitä, kuinka kauan osapuolet ovat ehtineet työskennellä yhdessä. Tällä nähtiin olevan vaikutusta sekä kollegiaalisissa että potilassuhteissa. Seuraavat otteet aineistosta on valittu TutTuUs-koodin perusteella:

Se on aina, et mitä pidempään jonkun kaa työskentelee, ni sen paremmin oppii sitymmärtämään. Et satunnaisessa kobtaamisessa se voi olla hyvinki vaikee ymmärtää, mutta sit ku pääsee taas niinku samalle aaltopituudelle, sit se paranee. [LÄÄKÄRI-LÄ̈̈KÄRI, Puhe, Tuttuus; KS2-L6]

Kyllä ihmeen hyvin on kumminki mun mielestä sujunut, ja paremmin nyt kun on pari vuotta kulunut, kun on tätä työtä tehty [yhdessä], ni se vaan sitte täytyy kysyä se toinen kerta ja selventää sitä asiaa, kun toinen kysyy, mikä se sana nyt onkaan. [Haastattelija: Nii siihen tottuu vai?] Joo. Ja potilaatkin tottuu.

[LÄÄKÄRI-HOITAJA, LÄÄKÄRI-POTILAS, TutTuUs; TK1-H16]

Toki täs on mun mielestä taas jälleen kerran se, et jos on pitkään ollu jo osastolla, ulkomaalaistaustainen, ni sit se kommunikaatio on toki paljon helpompaa. Et sit ku tulee joku ihan uutena, nikylsiin kestä̈̈ aika pitkä tovi, ennen ku se semmonen molemminpuolinen ymmärrys asioibin sitte syntyy.

[LÄÄKÄRI-HoitAja, TuttuUs; KS1H10]

Tutustumisen vaikutus kommunikoinnin helpottumiseen on todettu useissa tutkimuksissa (ks. esim. Major, 2007; Leinonen 2015). Sen on selitetty liittyvän ensinnäkin epätavalliseen ääntämiseen, intonaatioon sekä sanastollisiin ja rakenteellisiin poikkeamiin, joiden ymmärtämiseen harjaantuu ajan myötä (Gass
\& Varonis, 1984). Tutustumisen vaikutus liittyy myös yhteisen tietopohjan laajentumiseen, kun yhteisten kokemusten määrä lisääntyy (Whittaker, Frolich \& Daly-Jones, 1994). Tuttuuden merkitys kielitaitoon liittyvien ongelmien ehkäisyssä tulisikin huomioida paremmin potilas-lääkäri-suhteiden sekä työsuhteiden organisoinnissa esimerkiksi mahdollistamalla pitkäjänteisiä hoito- ja työsuhteita.

\section{Muut työtilanteiden ominaisuudet}

Haastateltavat nostivat esiin myös kokemuksen ja sen puutteen vaikutuksen. Mikäli lääkärillä ei ole kokemusta työtilanteesta, se vaikuttaa kielelliseen suoriutumiseen. Tähän aiheeseen liittyvät puheenvuorot on koodattu UUSI TILANNE -koodilla:

Kyllä mä joudun tulla apuun, kun joku taksikorttiasia mikä nytki tuli uus, ni kyllä me jouduttiin se menee ihan kädestä pitäen uudestaan, et miten se tehdään, vaikka se oli kyllä kokouksessa käyty läpitte, mutta sitte ku se käytännössä tulee ensimmästä kertaa eteen, ni kyllä se joudutaan menee ihan uudestaan vielä.

[Ohjeet, Kokoukset ja palaverit, Uusi tilanne, Kollegan tUKI; TK1H18]

No sellanen oli kielitaidosta, että meillä oli elvytystilanne, ja sehän on aina sellanen akuutti tilanne, jos on ensikertalainen siinä ja ensikertalaiset hoitajat, ni ne objeetja se vastuun ottaminen ei ollu ihan... niinku täyttä vastuuta ei ollu siitä, ni sitte kutsuttiin anestesialääkäri, ja se anestesialääkäri ei enää kommunikoinu sen lääkärin kanssa vaan anto suoraan objeita hoitajalle.

[LÄÄKÄRI-LÄÄKÄRI, LÄÄKÄRI-HOITAJa, Uusi tilanne, Aika, Kollegan TUKI; KS2-H15] 
Työtilanteen uutuus on suhteellinen käsite. Juuri aloittaneelle työntekijälle kaikki tilanteet voivat olla uusia, mutta toisaalta kokeneellakaan työntekijällä ei välttämättä ole kokemusta kaikista tilanteista, jotka kuitenkin kuuluvat työnkuvaan. Joillakin osastoilla esimerkiksi elvytystilanteet voivat olla hyvin harvinaisia mutta silti niissä on äärimmäisen tärkeää osata toimia oikein. Uusien tilanteiden vaikeus perustuu siihen, että usein toistuvien kommunikaatiostrategioiden käyttö on vaivattomampaa kuin harvoin esiintyvien (Street, 2003, s. 918). Lisäksi uudessa tilanteessa aiemman tiedon soveltaminen on työläämpää ja onnistuminen epävarmempaa kuin tutussa tilanteessa (Berger, 2003, s. 263).

Yksi tilanteen ominaisuus, jonka haastateltavat nostivat toistuvasti esiin, on kiire ja aikapaine. Aikataulultaan tiukka työtahti ja kiiretilanteet tuovat oman ylimääräisen haasteensa maahanmuuttajataustaisten lääkärien kielitaidolle. AıKA-koodilla merkittyjä puheenvuoroja ovat esimerkiksi seuraavat aineistonäytteet:

Ja sit kirjotetussa ei ebkä niin usein tuu ongelmaa, koska sitä he pystyy harkitsemaan pitempään, ei tarvitse nopeasti antaa sitä vastausta ja vähän niinku työstämään, et mitä tää on. Mut pubelimessa ku pitää niin nopeasti, ni se on vaarallinen se pubelin.

[Puhelinkeskustelu, Kirjoitus, AIKA; KS2-L2]

Ja se mikä tulee sitten ongelmaks näissä vastaanottotilanteissa, että ne on niin hektisiä ne tilanteet, ja sit henkilökunta kokee monesti, et joutuu sit paljon käyttää aikaa semmoseen opetustyöhön, mikä ei sit aina oo ihan belppo tilanne. Varsinkaan kiiretilanteissa ei oo mikään helppo asia.

[Kollegan tuki, Aika; PS-H7]

Tämä havainto vahvistaa tutkimustuloksia, joiden mukaan aikapaine nostaa kielitaidon vaatimusta korkeammaksi (Berger, 2003; Jäppinen, 2011). Kiireelliset työtilanteet vaativat nopeaa toimintaa, jossa vahvat rutiinit ovat tärkeitä (Berger, 2003, s. 256). Rutiinit ovat myös kielellisiä: mikäli henkilöllä on vahva kielitaito, auttaa se myös uusissa ja kiireellisissä tilanteissa toimimista. Tilanteen tuttuus voi kompensoida aikapaineen tuomaa haasteellisuutta, mutta erityisesti kokemuksen puute yhdistettynä kiireeseen nostaa kielitaidolle asetettavaa vaatimusta (mts.).

Haastatteluissa nousi voimakkaana esiin puhelinkeskustelun ongelmallisuus niin henkilökunnan välillä kuin potilasneuvonnassakin. Sitä pidettiin kaikkein riskialtteimpana tilannetyyppinä (Tervola, 2017). Erityisesti puhelimitse annettavat hoito- ja lääkemääräykset herättivät haastateltavissa huolta potilasturvallisuudesta. Seuraavat näytteet on valittu Puhelinkeskustelu-koodin perusteella:

Se korostuu just iltasin ja viikonloppusin, kun konsultoidaan [puhelimitse], ni sieltä tulee ohjeita näiltä muilta ulkomaalaistaustasilta lä̈käreiltä, et siellä sit tulee tämmösii et alkaa hälytyskellot soimaan. Tai sit tulee vaan määräys mut sä et edes kertonu siitä potilaasta mitään, sielt tuli määräys ja linja katkee vielkäsiin.

[PUhelinkeskustelu, LäÄKäRI-HOITAJA, EPÄVARMUUS; KS-H9]

Puhelimessa on se vakavin [ongelma]. $H y$ vin moni asiakas kyl sanoo, et pubelimessa ei saanu mitään selvää, et se oli ihan tyhjä pubelu. Et sit täytyy ottaa uudestaan yhteyttä tai mennä vastaanotolle, et aivan turhaa ollu se pubelu eikä oo jä̈ny mitään käteen. No siinähän on [hoitajan] kolmantena paha olla neuvomassa. Mut sit potilasvastaanottotilanteessa on niitä virheitä helpompikorjata. [Puhelinkeskustelu, LÄÄKÄRI-POTI- 


\section{LAS, UUSI VASTAANOTTOAIKA; KES-H2]}

Ja pubelinneuvonta [on ongelmallinen] sitte siinä, että ei voi käyttää elekieltä apuna eikä sitte nää sitä toista, että ymmärtääkö bän ja tulkita niinku eleistä.

[Puhelinkeskustelu, Eleet Ja IlMEET; KS2-H14]

Puhelinkeskusteluiden haasteellisuus kommunikoinnin kannalta perustuu ennen kaikkea visuaalisten vihjeiden puutteeseen. Puhtaasti kuuloaistiin perustuvan puheen tulkitseminen on epävarmaa ja vaikeuttaa ymmärtämistä, jolloin korostuu etukäteistiedon ja sanaston tuntemuksen merkitys (Bostrom, 2006, s. 276).

Kielellinen abstraktius nostettiin esiin ongelmia aiheuttavina tekijöinä. Erilaisten sanontojen, metaforien, huumorin sekä sanojen pienten sävyerojen koettiin tuottavan vaikeuksia maahanmuuttajataustaisille lääkäreille. Seuraavat näytteet on valittu koodien SÄvYerot, Abstraktiotaso, HuUmori ja SaNONNAT perusteella:

Se mikä ehkä korostuu täällä psykiatriassa, on mun mielestä ne abstraktit käsitteet, erilaiset tunteet ja sävyt ja niiden ymmärtäminen ja erottaminen, et ku ne ei oo konkreettisesti osotettavissa millä̈n muulla tavalla kun pubumalla. Eli sillon siitä muodostuu byvin usein sellanen ongelma, et niitä joudutaan hakemaan. Miten näytät, et ahdistaa? [LÄÄKÄRI-POTIlas, Mielenterveyspotilas, Sävyerot, Abstraktiotaso; PS-H6]

Sit potilas saattaa käyttää tämmöstä huumoria, se on asia, mikä ei oo yhtenevä meille välttämättä, taikka sananlaskut ja vertauskuvat. Kyl siinä aika paljon tulee hoitajan työssä sitä, että sä suomennat potilaalle sitte jälkikäteen, että mitä lääkäri tarkoitti ja mitä keskusteltiin. Tai sit potilaan sanomaa lääkärille. Ja tää on hyvä esimerkki tää ahdistus [viittaa edelliseen H6:n puheenvuoroon], että kerropas sitte tää ahdistus sanana, kun potilas näyttää, että häntä abdistaa, ni mitataanko EKG vai mitä tarkotat sillä, sydänfilmiä vai jotakin muuta. Et ne käsitteet sillä tavalla on erilaisia.

[LÄÄKÄRI-POTILAS, HuUMORI, SANONNAT, AbSTRAKTIOTASO; PS-H7]

Vaikka rupee olee tää lääketieteellinen sanasto jo kohtuullisen hallinnassa, ni sit just tällaset kielen nyanssit ja vähänkin tämmösistä syvällisimmistä asioista keskustelut, ni niissä hän ei tavallaan sit harjaannu tässä työssä sillä tavalla.

[Sanasto, Ammattitermit, Sävyerot, Abstraktiotaso; TK1-L7]

Abstraktien ja syvällisten asioiden käsitteleminen on kognitiivisesti vaativampaa kuin konkreettisten asioiden käsitteleminen, mikä johtuu pääasiassa kontekstin puuttumisesta (Met, 1994, s. 164). Lisäksi vaikeutta nostaa ymmärtämisen tulkinnallinen luonne. Esimerkiksi metaforan ymmärtäminen edellyttää useampia tulkintakehyksiä, jotka ovat usein kulttuurisidonnaisia (Dillard \& Marshall, 2003, s. 505). Samoin huumorin ymmärtäminen on melko kompleksinen prosessi, joka vaatii kykyä luoda kielen merkityksille vaihtoehtoisia tulkintoja (Wyer \& Adaval, 2003, s. 302).

Jotkut haastateltavat nostivat esiin myös erilaiset akustiset häiriötekijät, jotka vaikeuttavat puheenymmärtämistä erityisesti sairaalaolosuhteissa.

Ja ympäristö. Et täällä [sairaalassa] kaikupohja on erilainen, äänen sävyt on erilaisia. Jos on alentunutta kuuloa tai kuulolaitteita, ni tää ympäristö on erittäin huono semmosille momenteille. Että enemmän 
ottaa ne kuulolaitteet häiriöo tai sit just eri ä̈nenpainot, ylhä̈ltä, alhaalta, sävyt, tässä ympäristössä sotkeutuu. Et ulkona ja kotioloissa voi olla helpompi ymmärtää vierasta kieltä.

[KAIKU, HuONO KUULO; KES-H2]

Hälyisen ympäristön on todettu vaikeuttavan puheenymmärtämistä erityisesti vanhuksilla ja kuulolaitteen käyttäjillä (ks. esim. Takahashi \& Bacon, 1992; Nascimento \& Bevilacqua, 2005). Akustiset häiriötekijät nousivat keskusteluun erityisesti sairaalaympäristössä työskentelevillä haastateltavilla. Sairaaloiden akustiikka yhdistettynä potilaiden mahdollisiin kuulo-ongelmiin on tämän havainnon perusteella yhdistelmä, joka asettaa kielen selkeydelle ylimääräisiä haasteita.

\section{KRITEERIT TYÖTILANTEIDEN KIELELLISEN VAATIVUUDEN MÄÄRITTÄMISEKSI}

Kun analyysin tuloksia luokiteltiin kriteereiksi, tavoitteena oli mahdollisimman yleispätevät kriteerit, jotka yhdistävät samankaltaiset ominaisuudet yhteen ja toisaalta erottelevat erilaiset ominaisuudet erillisiksi kriteereiksi (ks. esim. Pill, 2016). Tutkimuksessa löydetyt tilanteiden ominaisuudet eivät muodosta yhtenäistä kokonaisuutta vaan ne liittyvät erilaisiin sosiaalisiin, psykologisiin ja kielellisiin ilmiöihin. Siten myöskään niistä johdetut kriteerit eivät ole täysin symmetriset.

Kriteerit johdettiin kokoamalla yhteen analyysissa löydetyt ominaisuudet ja yhdistelemällä samankaltaiset ominaisuudet yhdeksi kriteeriksi. Esimerkiksi työtilanteen osallistujiin liittyvät ominaisuudet osoittautuivat hyvin moninaiseksi kimpuksi, jossa toisaalta on kyse osapuolien henkilökohtaisista ominaisuuksista (taustatiedon ja käsitysten laatu ja kommunikointikykyyn vaikuttavat ominaisuudet), toisaalta osallistujien välisen suhteen ominaisuuksia (valta-asetelma ja vastuu tai tuttuus) tai osallistujien kollektiivisiin ominaisuuksiin (keskinäinen variaatio, ryhmätilanteet). Suurin osa kriteereistä abstrahoitiin suoraan löydetystä ominaisuudesta, kuten työtilanteen seuraukset, joista abstrahoitiin kriittisyys-kriteeri. Jotkin kriteerit on abstrahoitu yhdistämällä useampia ominaisuuksia, kuten esimerkiksi kieliriippuvuus, jossa yhdistyvät eri syyt, joiden vuoksi käsillä oleva konteksti ei tarjoa apua kielellisen viestin ymmärtämiseen. Seuraavaksi kokoan yhteen ja esittelen analyysin tulosten perusteella johdetut kriteerit:

Työtilanteen seuraukset ovat tämän tutkimuksen mukaan merkityksellinen tekijä kielellisen suoriutumisen kannalta. Seuraukset erottuvat muista ominaisuuksista siinä, että ne eivät liity kielenkäyttötilanteen vaikeuteen. Myös sinänsä helpot tilanteet voivat olla seurauksiltaan kohtalokkaita. Täten erilaiset tilanteiden seuraukset voidaan yhdistää yhdeksi kriteeriksi vakavuuden mukaan: mitä vakavampia seurauksia mahdollisella kommunikoinnin epäonnistumisella tilanteessa on, sitä tiukempi tulee olla myös kielitaitovaatimus. Nimitän tätä kriteeriä työtilanteen kriittisyydeksi (1).

Työtilanteen osapuoliin liittyviä ominaisuuksia tuli tutkimuksessa esiin useita. Yksi analyysin tulos on, että potilaiden kanssa keskustelu nähdään selvästi vaativampana kuin kollegoiden kanssa keskustelu. Analyysissa nousi useita syitä, joiden takia yleisesti katsottiin potilaan kanssa kommunikoinnin olevan haasteellisempaa kuin kollegoiden kanssa kommunikoinnin. Nämä syyt on jaettavissa kolmen otsikon alle: osallistujien välinen suhde, osallistujien yhteiset tiedot ja käsitykset sekä osallistujien variaatio kyvykkyyden ja ongelmien suhteen. Muotoilen näistä kriteerit seuraavasti:

Mikäli tilanteen toinen osapuoli (tai osapuolet) on henkilöön nähden heikossa tai 
haavoittuvassa asemassa, esimerkiksi jos henkilö on viranomainen, opettaja, asiantuntija, lääkäri tms., se nostaa tilanteen kielitaitovaatimusta. Jos taas osapuolet ovat tasavertaisia tai jos muut tilanteen osallistujat ovat vahvemmassa asemassa (esimerkiksi kokeneempi kollega), se on helpottava tekijä. Mitä suurempi vastuu henkilöllä on muista tilanteen osallistujista, sitä vahvempaa kielitaitoa tulee vaatia tilanteessa. Nimitän tätä kriteeriä sosiaaliseksi vastuuksi (2).

Mikäli toinen osapuoli jakaa samat taustatiedot ja käsitykset (esimerkiksi sama kulttuuri- ja ammattitausta), se tukee kommunikoinnin onnistumista ja yhteisymmärryksen syntymistä. Mikäli toisen osapuolen taustatiedot ja käsitykset poikkeavat huomattavasti henkilön omista, se lisää kielellistä vaativuutta. Tätä kriteeriä kutsun ybteiseksi taustatiedoksi (3).

Mikäli henkilön tilanteessa kohtaamat keskustelukumppanit ovat kyvyiltään ja ominaisuuksiltaan hyvin vaihtelevia, se nostaa kielitaidon vaatimusta. Mikäli toiset osapuolet taas ovat pitkälti toistensa kaltaisia taustaltaan ja tarpeiltaan, se tekee kommunikoinnista paremmin ennakoitavaa ja siten helpompaa. Tämä kriteeri liittyy myös 2 . kriteeriin sosiaalisesta vastuusta siten, että jos henkilö on jonkinlaisessa valta-asemassa toiseen osapuoleen nähden, hänen vastuullaan on myös mukautua toisten osapuolten vaihteleviin kommunikointitapoihin ja -kykyihin, kuten esimerkiksi lääkärin tai opettajan ammateissa. Kutsun tätä kriteeriä sosiaaliseksi variaatioksi (4).

Analyysissa nousi esiin myös sellaisia osallistujiin liittyviä ominaisuuksia, jotka koskevat yhtä lailla niin potilaiden kuin kollegoidenkin kanssa kommunikoimista. Yksi niistä on osallistujien keskinäinen tuttuus. Mikäli tilanteen osapuolet ovat tuttuja toisilleen eli osapuolilla on takanaan yhteistä työskentelyä tai muuta kanssakäymistä, se helpottaa kommunikointia ja tukee yhteisymmärryksen muodostumista. Toisilleen ennestään tuntemattomien osapuolten välillä taas kommunikointi on vaativampaa. Kutsun tätä kriteeriä sosiaaliseksi tuttuudeksi (5).

Toinen osallistujiin yleisesti liittyvä ominaisuus oli ryhmätilanteet. Mikäli samaan keskusteluun osallistuu useita henkilöitä, se on yksittäiselle henkilölle vaativampi tilanne kuin kahdenkeskinen tilanne. Kyse ei ole kuitenkaan osallistujien määrästä sinänsä, sillä esimerkiksi esitelmän pitämistä suurelle yleisölle ei koeta kovin vaativaksi, sillä siinä kommunikoinnin suunta on selkeä. Haastetta tuo nimenomaan se, jos useampi ihminen pyrkii kohti kollektiivista yhteisymmärrystä, jolloin jokainen osallistuja on sekä tuottaja että vastaanottaja. Nimitän tätä kriteeriä kommunikoinnin monisuuntaisuudeksi (6).

Yksi aineistossa esiin tullut tekijä liittyy sekä henkilöön että tilanteeseen, nimittäin tilanteen uutuus. Kuten analyysiosiossa todettiin, tilanteen uutuus voi liittyä henkilön kokemattomuuteen tai tilanteen harvinaisuuteen tai molempiin. Koska tässä tutkimuksessa tarkoituksena on luoda kriteereitä nimenomaan tilanteille, tästä tekijästä otan huomioon tilanteen ominaisuuden eli harvinaisuuden. Harvoin vastaan tulevat tilanteet ovat ongelmallisia, koska niihin on vaikea muodostaa rutiinia, joka helpottaisi tilanteesta suoriutumista. Harvinaiset tilanteet voivat kuitenkin olla tärkeitä työn kokonaisuuden kannalta, jolloin ne edellyttävät korkeampaa kielitaitoa. Siten harvinaiset tilanteet ovat vaativampia kuin usein toistuvat tilanteet. Kutsun tätä kriteeriä tilanteen harvinaisuudeksi (7).

Analyysissa tuli esiin aikapaine kommunikoinnin vaativuutta lisäävänä tekijänä. Kiiretilanteet vaativat vahvoja rutiineja ja nopeaa kommunikointia, mikä voi puutteellisella kielitaidolla osoittautua haasteelliseksi yhdistelmäksi. Kiireellisyys on usein myös yhteydessä kriittisyyteen; terveydenhuollossa 
kiiretilanteet ovat usein niitä, joissa potilaan terveys on vaakalaudalla. Tätä kriteeriä nimitän kiireellisyydeksi (8).

Kielellinen monitulkintaisuus, abstraktius ja epäsuoruus (huumori, sanonnat, vertaukset) mainittiin kielellistä vaativuutta nostavana ominaisuutena. Niiden ymmärtäminen vaatii kontekstin ylittävää tulkintaa sekä kulttuurista tietoa kielestä. Välittömän kontekstin puute on yksi vaikuttava tekijä myös siinä, miksi puhelinkeskustelut koetaan vaativiksi. Näitä kaikkia tilanteita yhdistää se, että puhujat joutuvat kommunikoimaan pitkälti kielellisen, tilannekontekstista vapaan merkityksen varassa (Kecskes, 2007), mikä yleensä onnistuu vasta runsaan kielenkäyttökokemuksen myötä. Yhdistän nämä tekijät kielellisen tiedon korostumisen kautta ja nimitän tätä kriteeriä kieliriippuvuudeksi (9). Tähän kriteeriin liittyvät myös kirjoitetut tekstit, joissa kommunikointi täytyy rakentaa itsenäisesti toimivaksi viestiksi usein pelkästään kielellisin keinoin.

Viimeisenä analyysissa nousivat esiin erilaiset tilanteen häiriötekijät. Haastatteluissa mainitut häiriöt olivat lähinnä akustiikkaan liittyviä, kuten kaiku ja melu. Myös ryhmätilanteiden yhteydessä mainittu keskustelun poukkoilevuus ja päällekkäin puhuminen voidaan sisällyttää akustisiin tekijöihin. Yhdistän nämä tekijät yhdeksi kriteeriksi ja kutsun sitä akustisiksi häiriötekijöiksi (10).

\section{Kriteerien arviointia}

Yllä esitetyt kymmenen kriteeriä on johdettu terveydenhuollon ammattilaisten haastattelujen pohjalta. Näin saatiin näkyviin erityisesti terveydenhuoltoalan käytännön työn näkökulma kielelliseen vaativuuteen. Terveydenhuollon ammattilaiset katsoivat kielellistä suoriutumista toiminnan onnistumisen näkökulmasta, johon kuuluu olennaisena osana potilaan asema hoidon saajana. Kui- tenkin potilaiden oman näkökulman kuuleminen voisi tuoda sellaista lisävalaistusta lääkärien kielelliseen suoriutumiseen, jota tämän tutkimuksen aineistolla ei tavoiteta. Esimerkiksi huonojen uutisten kertomista potilaalle tai omaisille pidetään yleisesti vaativana tehtävänä sairaanhoidossa (Kurtz ym., 2005, s. 204), mutta se ei noussut esiin tässä tutkimuksessa. On mahdollista, että huonojen uutisten kertomiseen liittyvät ongelmat jäävät potilaan ja lääkärin välille eivätkä tule kollegoiden tietoon. Toinen mahdollinen selitys on, että huonojen uutisten kertominen on vaativaa kaikille eikä erityisesti korostu maahanmuuttajataustaisten lääkärien kohdalla. Kriteerit on abstrahoitu siten, että ne ovat sovellettavissa muidenkin ammattialojen työtilanteiden kuvaukseen. Muita ammatteja ja aloja tutkimalla on kuitenkin mahdollista löytää myös lisää kriteereitä.

On myös huomattava, että kriteerit on johdettu terveydenhuollon arjesta epäsuorasti. Suora työtilanteiden havainnointi ja kommunikoinnin onnistumisen arviointi voisi tuoda kiinnostavia lisänäkökulmia tuloksiin, mutta toisaalta metodologiset ongelmat siinä, miten arvioinnin läsnäolo aktuaalisessa tilanteessa vaikuttaa osapuoliin ja heidän suoriutumiseensa, ovat olemassa. Suoran havainnoinnin perusteella ei myöskään pystytä tavoittamaan kommunikaatio-ongelman merkityksellisyyttä tai merkityksettömyyttä toiminnan kokonaisuuden kannalta, vaan siihen vaaditaan alalla toimivien ammattilaisten arviota (Elder ym., 2017; Pill \& McNamara, 2016).

Näistä erityisesti osallistujiin liittyvät kriteerit sosiaalinen vastuu, ybteinen taustatieto ja sosiaalinen tuttuus sekä kiireellisyys on nostettu esiin myös pedagogisten tehtävien haasteellisuutta määritettäessä (Robinson, 2001, s. 30). Muutoin pedagogisten tehtävien kriteerit ovat usein täsmällisempiä kuin tämän tutkimuksen kriteerit työtilanteille. Pedagogisia tehtäviä laadittaessa voidaan esimer- 
kiksi määrittää tarkasti puheenaihe, tehtävän vaiheiden lukumäärä tai tehtävän vaatiman järkeilyn luonne (mts.). Tällaiset kriteerit ovat nähdäkseni kuitenkin liian pikkutarkkoja autenttisten työtilanteiden vaativuuden määrittämiseen.

\section{POHDINTAA}

Tässä tutkimuksessa osoitettiin haastatteluaineiston sisällönanalyysin avulla, että lääkärin työtilanteilla on ominaisuuksia, jotka ovat yhteydessä maahanmuuttajataustaisten lääkärien kielelliseen suoriutumiseen tai suoriutumattomuuteen. Sisällönanalyysin perusteella maahanmuuttajataustaisen lääkärin kielelliseen pärjäämiseen vaikuttavat ominaisuudet liittyvät työtilanteen seurauksiin, tilanteen osallistujiin, aikaan sekä ympäristöön. Yhteydet tilanteen ominaisuuksien ja kielellisten ongelmien välillä näyttäytyvät analyysin perusteella selkeinä. Yhtään ristiriitaista yhteyttä ei aineistosta havaittu, yksikään tilanteen ominaisuus ei siis yhdistynyt sekä kielelliseen suoriutumiseen että suoriutumattomuuteen. Eri ammattiryhmiä edustavat haastateltavat olivat yhdistäneet tilanteen ominaisuuksia hyvin samoin tavoin, mutta konkreettisia kielitaidon puutteellisuuteen liittyviä haasteita oli kohdannut enemmän hoitohenkilökunta kuin lääkärit (Tervola, 2017).

Löydetyistä ominaisuuksista muokattiin kymmenen kriteeriä, joiden avulla voidaan määritellä työtehtävien kielellistä vaativuutta. Nämä kriteerit ovat kriittisyys, sosiaalinen vastuu, ybteinen taustatieto, sosiaalinen variaatio, sosiaalinen tuttuus, kommunikoinnin monisuuntaisuus, tilanteen harvinaisuus, kiireellisyys, kieliriippuvuus ja akustiset häiriötekijät. Kriteerit kuvaavat pitkälti samoja ilmiöitä, jotka on kommunikoinnin tutkimuksissa havaittu yleisestikin haasteellisiksi (Greene \& Burleson, 2003; Hargie, 2006b; Kurtz ym., 2005). Vahva kielitaito on näiden haasteiden voittamisessa ehdoton etu, kun taas heikolla kielitaidolla haasteet muuttuvat usein ylitsepääsemättömiksi (Berger, 2003, s. 267). Vahva kielitaito osoittautuu tärkeäksi siis juuri silloin, kun ympäröivä tilanne tarjoaa tukea vain vähän. Kieli- ja kommunikointitaitoisella henkilöllä on joustava ja laaja valikoima vaihtoehtoja, joiden avulla hän pystyy sopeutumaan erilaisiin kommunikatiivisiin olosuhteisiin eikä ole riippuvainen tilanteissa mahdollisesti saatavilla olevista ulkoisista tuista (Street, 2003, s. 918).

On kuitenkin selvää, että kielelliseen suoriutumiseen aktuaalisessa tilanteessa vaikuttavat tekijät ovat moninaisia, eikä vahva kielitaito ole tae hyvästä suoriutumisesta. Se antaa kuitenkin selvän etumatkan tilanteissa niihin nähden, joiden kielitaito on heikompi. Kielitaidon lisäksi etua on myös esimerkiksi toimintaympäristön tuntemuksesta sekä yleisistä sosiaalisista taidoista (Hargie, 2006a; Huhta, Jaatinen ym., 2006, s. 51).

Tässä tutkimuksessa johdetut tilanteiden kriteerit vertautuvat erityisalojen kielitaitotutkimuksessa hiljattain jalansijaa saaneeseen näkemykseen luontaisista kriteereistä ("indigenous criteria”, Elder \& McNamara, 2016; Erdősy, 2009; Pill, 2016; ). Sen kantavana ajatuksena on suhteuttaa kielellisen suoriutumisen arviointi erityisalan omiin tavoitteisiin ja käytänteisiin. Kuten Huhta, Jaatinen ja Johnson huomauttavat (2006, s. 44), "[k]ontekstin ulkopuolella laaditut järjestelmät eivät tuo ratkaisua kieltenopetuksen arvioinnin kehittämiseen”. Luontaisia kriteereitä on käytetty erityisesti kielellisen suorituksen arviointiin (Knoch ym., 2015; O’Hagan, Pill \&Zhang, 2016). Tässä tutkimuksessa periaate on sama mutta kielellistä suoriutumista ei arvioida suoraan vaan työtilanteen onnistumisen kautta, jolloin sitä pystyvät parhaiten arvioimaan juuri alan kokeneet ammattilaiset. Tämä on myös funktionaalisen kielitaitokäsityksen perusajatus; kielitaitoa arvioidaan sillä 
perusteella, miten hyvin se toimii tarkoituksessaan ja mahdollistaa tehtävien menestyksekkään suorittamisen (Kalliokoski, 2017, s. 109; Kela \& Komppa, 2011). Tämä myös nostaa keskiöön erityisalojen kielitaidon merkityksen yleiskielitaitoon nähden: erityisalan kielitaitoa voidaan pätevästi arvioida vain, kun tunnetaan erityisalan toiminnalliset vaatimukset.

Tässä tutkimuksessa tuotettujen kriteerien tavoitteena onkin juuri tuoda erityisalojen kielitaitovaatimuksiin niitä elementtejä, jotka todellisuudessakin vaikuttavat erityisalan ympäristössä. Niiden avulla on mahdollista siten päästä paremmin käsiksi ammatillisen kielenopetuksen ydinkysymykseen siitä, mikä on riittävää kielitaitoa. Kun alan tai ammatin kielitaitovaatimuksia määritetään, voidaan työtilanteiden kriteereiden avulla määrittää suhteellisen selkeästi, millainen kielitaitotaso on kyseisessä ammatissa tai jopa yksittäisessä työpaikassa riittävä. Kun kielitaidon riittävyys määritellään alan omien toiminnallisten vaatimusten pohjalta, voidaan välttyä myös liialliselta kielikeskeisyydeltä (Hyland 2002, s. 393). Mikä tahansa puute kielellisessä suoriutumisessa ei vaikuta riittävyyteen vaan ainoastaan sellaiset, jotka haittaavat työn onnistumista.

Kriteerien soveltamista varten tulee kartoittaa ammatin tai työpaikan työtilanteet, jotka arvioidaan kriteerien avulla. Mikäli ammatin työnkuvaan sisältyy kielellisesti vaativia työtilanteita, on ammattiin pyrkiville asetettava niiden mukainen kielitaitovaatimus, mikä velvoittaa myös ammatillista koulutusta ja täydennyskoulutusta määrittämään tavoitteensa vaatimusten mukaisiksi. Kriteerien avulla myös ammatinvalintaa harkitsevat voivat saada realistisen käsityksen ammatin vaatimasta kielitaidon tasosta. Toisaalta kriteerit voivat auttaa myös työnantajaa mukauttamaan työnkuvaa vastaamaan paremmin työntekijän senhetkistä kielitaidon tasoa. Tällöin työntekijälle voidaan esimerkiksi järjestää tukea vaativiin työtilanteisiin, kunnes kielitaito on kehittynyt vahvemmaksi. Työympäristön tuen avulla kielitaitoa onkin mahdollista kehittää vielä paljon, mikä koskee erityisesti ulkomailla koulutetun lääkärin ammattilupaan liittyvää harjoittelua (Maahanmuuttajalääkärien koulutuspolku, 2017). Tämän tutkimuksen perusteella kannustan erityisalojen ammattilaisia, kouluttajia ja kieliasiantuntijoita työskentelemään yhdessä ala- ja ammattikohtaisten kielitaitovaatimusten laatimiseksi.

\section{LÄHTEET}

Alastalo, M. \& Åkerman, M. (2010). Asiantuntijahaastattelun analyysi: Faktojen jäljillä. Teoksessa J. Ruusuvuori \& P. Nikander (toim.), Haastattelun analyysi, (s. 372-392). Tampere: Vastapaino.

Asetus $1998=$ Asetus opetustoimen henkilöstön kelpoisuusvaatimuksista 14.12.1998/986, \$9.

Asetus $2003=$ Valtioneuvoston asetus suomen ja ruotsin kielen taidon osoittamisesta valtionhallinnossa, 12.6.2003/481, \$13.

Baig, L. A., Violato, C. \& Crutcher, R. A. (2009). Assessing clinical communication skills in physicians: Are the skills context specific or generalizable. BMC Medical Education, 9, 22.

Berger, C. (2003). Message production skills in social interaction. Teoksessa J. Greene \& B. Burleson (toim.), Handbook of communication and social interaction skills, (s. 257-290). Mahwah: Lawrence Erlbaum Associates.

Bostrom, R. (2006). The process of listening. Teoksessa O. Hargie (toim.), Handbook of communication skills, (s. 267-292). Hove: Routledge.

Boulet, J., van Zanten, M., McKinley, D. \& Gary, N. (2001). Evaluating the spoken English proficiency of graduates of foreign medical schools. Medical Education, 35, 767-773.

Brindley, P. \& Reynolds, S. (2011). Improving verbal communication in critical care medicine. Journal of Critical Care, 26, 155-159.

Brown, G. (2006). Explaining. Teoksessa O. Hargie (toim.), Handbook of communication skills, 
(s. 195-228). Hove: Routledge.

Byrnes, H. (2002a). Toward academic-level foreign language abilities: Reconsidering foundational assumptions, expanding pedagogical options. Teoksessa B. Leaver \& B. Shektman (toim.), Developing professional-level language proficiency, (s. 34-58). Cambridge: Cambridge University Press.

Byrnes, H. (2002b). Contexts for advanced foreign language learning. A report on an immersion institute. Teoksessa B. Leaver \& B. Shektman (toim.), Developing professional-level language proficiency, (s. 61-76). Cambridge: Cambridge University Press.

Chur-Hansen, A., Vernon-Roberts, J. \& Clark, S. (1997). Language background, English language proficiency and medical communication skills of medical students. Medical Education, 31,259-263.

Cormier, D. C., McGrew K. S. \& Evans, J. J. (2011). Quantifying the "degree of linguistic demand" in spoken intelligence test directions. Journal of Psychoeducational Assessment, 29, 515-533.

Craig, R., Moxey, L., Young, D., Spenceley, N. \& Davidson, M. (2012). Strengthening handover communication in pediatric cardiac intensive care. Pediatric Anesthesia, 22, 393-399.

Dillard, J. P. \& Marshall, L. (2003). Persuasion as a social skill. Teoksessa J. Greene \& B. Burleson (toim.), Handbook of communication and social interaction skills, (s. 479-514). Mahwah: Lawrence Erlbaum Associates.

Douglas, D. (2000). Assessing languages for specific purposes. Cambridge: Cambridge University Press.

Edwards, J. \& Templeton, A. (2005). The structure of perceived qualities of situations. European Journal of Social Psychology, 35, 705-723.

Eggly, S., Musial, J. \& Smulowitz, J. (1999). Research and discussion note: The relationship between English language proficiency and success as a medical resident. English for Specific Purposes, 18, 201-208.

Elder, C. \& McNamara, T. (2016). The hunt for "indigenous criteria" in assessing communication in the physiotherapy workplace. Language Testing, 33, 153-174.

Elder, C., McNamara, T., Kim, H., Pill, J. \& Sato, T. (2017). Interrogating the construct of com- municative competence in language assessment contexts: What the non-language specialist can tell us. Language \& Communication, 57, 14-21.

Elder, C., McNamara, T., Woodward-Kron, R., Manias, E., McColl, G., Webb, G., Pill, J. \& O'Hagan, S. (2013). Developing and validating language proficiency standards for non-native English speaking health professionals. Papers in Language Testing and Assessment, 2, 66-70.

Eraut, M. (1994). Developing professional knowledge and competence. Lontoo: The Falmer Press.

Erdősy, M. U. (2009). Chasing Proteus: Identifying indigenous assessment criteria in academic settings. Teoksessa A. Brown \& K. M. Hill (toim.), Tasks and criteria in performance assessment, (s. 111-133). Frankfurt am Main: Peter Lang.

Eskola-Kronqvist, A. \& Hirard, T. (2016). Valmentava koulutus vie maahan muuttanutta elämässä eteenpäin, HAMK Unlimited: Journal 22.11.2016. Haettu 26.1.2018 osoitteesta https://unlimited.hamk.fi/ammatillinenosaaminen-ja-opetus/valmentava-koulutusvie-maahan-muuttanutta-elamassa-eteenpain/

Gass, S. \& Varonis, E. M. (1984). The effect of familiarity on the comprehensibility of nonnative speech. Language Learning, 34, 65-87.

Gibson, D. R. (2003). Participation shifts: Order and differentiation in group conversation. Social Forces, 81, 1335-1380.

Greene, J. \& Burleson, B. (2003). Handbook of communication and social interaction skills. Mahwah: Lawrence Erlbaum Associates.

Hargie, O. (2006a). Skill in theory: Communication as skilled performance. Teoksessa O. Hargie (toim.), Handbook of communication skills, (s. 7-36). Hove: Routledge.

Hargie, O. (2006b). Skill in practice: An operational model of communicative performance. Teoksessa O. Hargie (toim.), Handbook of communication skills, (s. 37-70). Hove: Routledge.

Hsueh-Chao, M. \& Nation, P. (2000). Unknown vocabulary density and reading comprehension. Reading in a Foreign Language, 13, 403-430.

Huhta, M., Jaatinen, R. \& Johnson, E. (2006). Työelämään valmentavan kieltenopetuksen perusteet. Teoksessa M. Huhta, E. Johnson, U. Lax \& S. Hantula (toim.), Työelämän kieli-ja viestintätaito. Kohti ammatillisen kielen täsmäopetusta, (s. 32-57). Sarja A: Tutkimukset 
ja raportit 8 . Helsinki: Helsingin ammattikorkeakoulu Stadian julkaisuja.

Huhta, M., Johnson, E., Lax, U. \& Hantula, S. (toim.) (2006). Työelämän kieli-ja viestintätaito. Kobti ammatillisen kielen täsmäopetusta. Sarja A: Tutkimukset ja raportit 8. Helsinki: Helsingin ammattikorkeakoulu Stadian julkaisuja.

Hutchinson, T. \& Waters, A. (1987). English for specific purposes. A learning-centered approach. Cambridge: Cambridge University Press.

Hyland, K. (2002). Specificity revisited: How far should we go now? English for Specific Purposes, 21, 385-395.

Hyland, K. \& Hamp-Lyons, L. (2002). EAP: Issues and directions. Journal of English for Academic Purposes, 1, 1-12

Härmälä, M. (2008). Riittääkö Ett ögonblick näytöksi merkonomilta edellytetystä kielitaidosta? Kielitaidon arviointi aikuisten näyttötutkinnoissa. Jyväskylä Studies in Humanities 101. Jyväskylä: Jyväskylän yliopisto.

Härmälä, M. (2013). Näkökulmia ammatilliseen kielitaitoon ja sen arviointiin. Teoksessa A. Räisänen (toim.), Oppimisen arvioinnin kontekstit ja käytännöt, (s. 309-317). Opetushallituksen raportit ja selvitykset 3 .

Iwashita, N., McNamara, T. \& Elder, C. (2001). Can we predict task difficulty in an oral proficiency test? Exploring the potential of an information-processing approach to task design. Language Learning, 51, 401-436.

Johns, G. (2006). The essential impact of context on organizational behavior. Academy of Management Review, 31, 386-408.

Johnson, P. (1982). Effects on reading comprehension of background knowledge. TESOL Quarterly, 16, 503-516.

Juurakko-Paavola, T. \& Mård-Miettinen, K. (2012). Työelämälähtöistä ja alakohtaista kieltenopetusta, Kieli, koulutus ja yhteiskunta, joulukuu 2012. Haettu 2.2.2018 osoitteesta https://www.kieliverkosto.fi/fi/journals/kielikoulutus-ja-yhteiskunta-joulukuu-2012

Jäppinen, T. (2010). Suomi (S2) korkeakoulutettujen työssä - Millainen kielitaito riittää? Teoksessa M. Garant \& M. Kinnunen (toim.), AFinLA-e: Soveltavan kielitieteen tutkimuksia, 2, (s. 4-16). Haettu 2.2.2018 osoitteesta https://journal.fi/afinla/article/view/3872

Jäppinen, T. (2011). Suomen kielen taidon riit- tävyys yritysten aikapaineisissa puhetilanteissa esimiesten ja työharjoittelijoiden kuvaamana. Pube ja kieli, 31, 193-214.

Kalliokoski, J. (2017). Virkakielen ihanteet ja kielen omistajuus: S2-näkökulmia julkishallinnon kielenkäyttöön. Teoksessa S. Latomaa, E. Luukka \& N. Lilja (toim.), AFinLAn vuosikirja 2017. Kielitietoisuus eriarvoistuvassa yhteiskunnassa. Language awareness in an increasingly unequal society, (s. 92-113). Jyväskylä: Suomen soveltavan kielitieteen yhdistys.

Kecskes, I. (2007). Dueling contexts: A dynamic model of meaning. Journal of Pragmatics, 40, 385-406.

Kela, M. \& Komppa, J. (2011). Sairaanhoitajan työkieli: yleiskieltä vai ammattikieltä? Funktionaalinen näkökulma ammattikielen oppimiseen toisena kielenä. Puhe ja kieli, 31, 173-192.

Kielimuurin yli (2013). Suositukset korkeakoulutettujen maahanmuuttajien suomen kielen oppimisen ja työllistymisen edistämiseksi. ONE Baltic Sea Region -hankkeen verkkodokumentti. Haettu 26.1.2018 osoitteesta http://www. helsinki.fi/urapalvelut/ONE_BSR/kielimuurin_yli_raportti.pdf

Knoch, U., McNamara, T., Woodward-Kron, R., Elder, C., Manias, E., Flynn, E. \& Zhang, Y. (2015). Towards improved language assessment of written health professional communication: the case of the Occupational English Test. Papers in Language Testing and Assessment, 4, 60-66.

Kokkonen, M. (2007). Vaatimuksena sujuva suomi. Virittäjä, 111, 253-261.

Komppa, J. (2015). Työnantajan odotukset, työntekijän vastuu ja työyhteisön tuki. Näkökulmia korkeakoulutettujen maahanmuuttajien ammatillisen suomen oppimiseen. AFinLA-e: Soveltavan kielitieteen tutkimuksia, 8, 168-185.

Komppa, J., Jäppinen, T., Herva, M. \& Hämäläinen, T. (2014). Korkeakoulutuksen ammatilliset suomi toisena kielenä-viitekehykset. Metropolia ammattikorkeakoulun Aatos-artikkelit 16. Haettu 26.1.2018 osoitteesta http:// www.metropolia.fi/palvelut/julkaisutoiminta/ julkaisusarjat/aatos-artikkelit/komppa-jappinen-herva-hamalainen/

Krauss, R. M. \& Fussell, S. R. (1990). Mutual knowledge and communicative effectiveness. Teoksessa J. Galegher, R. E. Kraut \& C. Egi- 
do (toim.), Intellectual teamwork. Social and technological foundations of cooperative work, (s. 111-145). New York: Lawrence Erlbaum Associates.

Kurtz, S., Silverman, J. \& Draper, J. (2005). Teaching and learning communication skills in medicine. Oxford: Radcliffe Publishing.

Leinonen, A. (2015). "Riittää, kun saa selvää". Vieraalla aksentilla tuotettu suomi nuorten arvioimana. Jyväskylä Studies in Humanities 275. Jyväskylä: Jyväskylän yliopisto.

Lilja, N., Luukka, E. \& Latomaa, S. (2017). Kielitietoisuus eriarvoistumiskehitystä jarruttamassa. Teoksessa S. Latomaa, E. Luukka \& N. Lilja (toim.), AFinLAn vuosikirja 2017. Kielitietoisuus eriarvoistuvassa yhteiskunnassa, (s. 11-29). Jyväskylä: Suomen soveltavan kielitieteen yhdistys.

Lloyd, M. \& Bor, R. (2009). Communication skills for medicine. Lontoo: Churchill Livingstone Elsevier.

Maahanmuuttajalääkärin koulutuspolku 2017 = Maahanmuuttajalääkärin koulutuspolku -hankkeen loppuraportti ja toimintamalleja. Haettu 26.1.2018 osoitteesta https://research.uta.fi/ maahanmuuttajalaakarit/

Mahajan, J. \& Stark, P. (2007). Barriers to education of overseas doctors in paediatrics: A qualitative study in South Yorkshire. Archives of Disease in Childhood, 92, 219-223.

Major, R. C. (2007). Identifying a foreign accent in an unfamiliar language. Studies in Second Language Acquisition, 29, 539-556.

Merton, R. K., Fiske, M. \& Kendall, P. L. $(1990$ [1956]). The focused interview. A manual of problems and procedures. Glencoe, USA: Free Press.

Met, M. (1994). Teaching content through a second language. Teoksessa F. Genesee (toim.), Educating second language children, (s. 159182). Cambridge: Cambridge University Press.

Meyer, R. (2009). Defining the nature and structure of work situations. Väitöskirja. Purdue University.

Nascimento, L. T. \& Bevilacqua, M. C. (2005). Evaluation of speech perception in noise in cochlear implanted adults. Brazilian Journal of Otorbinolaryngology, 71, 432-438.

O'Hagan, S., Pill, J. \& Zhang, Y. (2016). Extending the scope of speaking assessment criteria in a specific-purpose language test: Operationalizing a health professional perspective. Language Testing, 33, 195-216.

OKM, 2016 = Maahanmuuttajien koulutuspolut ja integrointi - kipupisteet ja toimenpide-esitykset. Opetus- ja kulttuuriministeriön julkaisuja 2016:1.

OKM, 2017 = Maahanmuuttajien koulutuspolut ja integrointi-kipupisteet ja toimenpide-esitykset II. Opetus- ja kulttuuriministeriön julkaisuja 2017:5.

OPH, $2015=$ Opetushallitus. Ammatillisten perustutkintojen perusteet. Haettu 26.1.2018 osoitteesta http://oph.fi/saadokset_ja_ohjeet/ opetussuunnitelmien_ja_tutkintojen_perusteet/ammatilliset_perustutkinnot

Pill, J. (2016). Drawing on indigenous criteria for more authentic assessment in a specific-purpose language test: Health professionals interacting with patients. Language Testing, 33, 175-193.

Pill, J. \& McNamara, T. (2016). How much is enough? Involving occupational experts in setting standards on a specific-purpose language test for health professionals. Language Testing, 33, 217-234.

Pöyri, M., Kóllar, N., Karukivi, M. \& HaapasaloPesu, K.-M. (2014). Maahanmuuttajalääkärien perehdytys psykiatriseen sairaanhoitoon. Suomen Lä̈̈kärilehti, 22, 1660-1.

Reader, T., Flin, R. \& Cuthbertson, B. (2007). Communication skills and error in the intensive care unit. Current Opinion in Critical Care, 13, 732-736.

Robinson, P. (2001). Task complexity, task difficulty, and task production: Exploring interactions in a componential framework. Applied Linguistics, 22, 27-57.

Rowan, K. (2003). Informing and explaining skills: Theory and research of informative communication. Teoksessa J. Greene \& B. Burleson (toim.), Handbook of communication and social interaction skills, (s. 403-438). Mahwah: Lawrence Erlbaum Associates.

Saeed, J. (2005 [1997]). Semantics. Hong Kong: Blackwell Publishing.

Sajavaara, A. \& Salo, M. (2007). Työelämän kielitaitotarpeet ja kielikoulutus. Teoksessa S. Pöyhönen \& M.-R. Luukka (toim.), Kobti tulevaisuuden kielikoulutusta. Kielikoulutuspoliittisen projektin loppuraportti, (s. 233-252). Jyväskylä: 
Soveltavan kielentutkimuksen keskus.

Shapiro, A. M. (2004). How including prior knowledge as a subject variable may change outcomes of learning research. American Educational Research Journal, 41, 159-189.

Skehan, P. (1996). A framework for the implementation of task-based instruction. Applied Linguistics, 17, 38-62.

Skehan, P. (1998). A cognitive approach to language learning. Oxford: Oxford University Press.

Street, R. (2003). Interpersonal communication skills in health care contexts. Teoksessa J. Greene \& B. Burleson (toim.), Handbook of communication and social interaction skills, (s. 909-934). Mahwah: Lawrence Erlbaum Associates.

Strömmer, M. (2016). Affordances and constraints: Second language learning in cleaning work. Multilingua: Journal of Cross-Cultural and Interlanguage Communication, 35, 697721.

Suni, M. (2011). Missä ja miten maahanmuuttajat kehittävät ammatillista kielitaitoaan? Ammattikasvatuksen aikakauskirja, 13, 8-22.

Takahashi, G. \& Bacon, S. (1992). Modulation detection, modulation masking, and speech understanding in noise in the elderly. Journal of Speech and Hearing Research, 35, 1410-21.

Tarnanen, M., Huhta, A. \& Pohjala, K. (2007). Mitä on osaaminen? Kielitaidon arviointi vastaajana. Teoksessa S. Pöyhönen \& M.-R. Luukka (toim.), Kohti tulevaisuuden kielikoulutusta. Kielikoulutuspoliittisen projektin loppuraportti, (s. 381-412). Jyväskylä: Soveltavan kielentutkimuksen keskus.

Tarnanen, M. \& Pöyhönen, S. (2011). Maahanmuuttajien suomen kielen taidon riittävyys ja työllistymisen mahdollisuudet. Puhe ja kieli, 31, 139-152.
Tervola, M. (2017). Työelämän näkökulma maahanmuuttajataustaisten lääkärien kielitaitoon. Sosiaalilääketieteellinen Aikakauslebti, 54, 196-208.

Valvira 2016 = Kielitaito, 25.2.2016. Haettu 26.1.2018 osoitteesta http://www.valvira.fi/ terveydenhuolto/ammattioikeudet/ulkomailla-suoritetut-opinnot/kielitaito

Virtanen, A. (2011). Käsityksiä kansainvälisesti rekrytoitujen hoitajien ammatillisesta kielitaidosta ja sen kehittymisestä. Mediakeskusteluiden ja asiantuntijan haastattelun analyysia. Puhe ja kieli, 31, 153-172.

Virtanen, A. (2017). Toimijuutta toisella kielellä: kansainvälisten sairaanhoitajaopiskelijoiden ammatillinen suomen kielen taito ja sen kehittyminen työharjoittelussa. Jyväskylä Studies in Humanities 311. Jyväskylän yliopisto.

Vuori, H. (2013). Terveydenhuollon laatutyön kehitys Suomessa. Sosiaalilääketieteellinen Aikakauslehti, 50, 87-95.

Whittaker, S., Frolich, D. \& Daly-Jones, O. (1994). Informal workplace communication. What is it like and how might we support it? Proceedings of the SIGCHI Conference on $\mathrm{Hu}$ man Factors in Computing Systems, 131-137.

Wit, A. (2006). Interacting in groups. Teoksessa O. Hargie (toim.), Handbook of communication skills, (s. 383-402). Hove: Routledge.

Wyer, R. \& Adaval, R. (2003). Message reception skills in social communication. Teoksessa J. Greene \& B. Burleson (toim.), Handbook of communication and social interaction skills, (s. 291-356). Mahwah: Lawrence Erlbaum Associates. 


\section{DETERMINING THE LINGUISTIC DEMAND OF PHYSICIAN'S WORK SITUATIONS}

Maija Tervola, University of Tampere

In professional language education and testing, there is a need for more precise knowledge of the quality of language requirements in different fields and professions. Nowadays it is common to see language skills as situational, but the concept of situation lacks proper definition and there is no proper analysis of the properties of situations. The aim of this article is to use co-workers' interviews ( $\mathrm{n}=32)$ to determine the linguistic demand of physician's work situations. With the help of thematic content analysis, I searched for features that are associated with immigrant physicians' linguistic performance. The features concern for example consequences and participants of situations. Based on the analysis, ten criteria were formulated which determine the linguistic demand of physician's work situations: criticalness, social responsibility, shared background knowledge, social variation, social familiarity, multidirectional communication, rareness, urgency, language dependency, and distraction. These criteria aim to improve validity of language education and testing in terms of the actual language demands of the work place. Criteria are abstracted from the data so that they are applicable to other professions as well. On the other hand, data from other professions may yield additional criteria.

Keywords: criteria, Finnish as a second language, language demand, physician, professional language skills, work situations 